OPEN ACCESS

Edited by:

Lin Lin,

Jiangsu University, China

Reviewed by:

Marwan M. A. Rashed,

Yibin University, China

Vipin Kumar Singh,

Banaras Hindu University, India

${ }^{*}$ Correspondence:

Costantino Paciolla

costantino.paciolla@uniba.it

Specialty section:

This article was submitted to

Food Microbiology,

a section of the journal

Frontiers in Microbiology

Received: 05 November 2019

Accepted: 31 January 2020

Published: 12 March 2020

Citation:

Loi M, Paciolla C, Logrieco AF and Mulè G (2020) Plant Bioactive Compounds in Pre- and Postharvest

Management for Aflatoxins

Reduction. Front. Microbiol. 11:243.

doi: 10.3389/fmicb.2020.00243

\section{Plant Bioactive Compounds in Pre- and Postharvest Management for Aflatoxins Reduction}

\author{
Martina Loi'1, Costantino Paciolla ${ }^{2 *}$, Antonio F. Logrieco' ${ }^{1}$ and Giuseppina Mulè' \\ ${ }^{1}$ Institute of Sciences of Food Production, Italian National Research Council, Bari, Italy, ${ }^{2}$ Department of Biology, University \\ of Bari "Aldo Moro," Bari, Italy
}

Aflatoxins (AFs) are secondary metabolites produced by Aspergillus spp., known for their hepatotoxic, carcinogenic, and mutagenic activity in humans and animals. AF contamination of staple food commodities is a global concern due to their toxicity and the economic losses they cause. Different strategies have been applied to reduce fungal contamination and AF production. Among them, the use of natural, plant-derived compounds is emerging as a promising strategy to be applied to control both Aspergillus spoilage and AF contamination in food and feed commodities in an integrated pre- and postharvest management. In particular, phenols, aldehydes, and terpenes extracted from medicinal plants, spices, or fruits have been studied in depth. They can be easily extracted, they are generally recognized as safe (GRAS), and they are foodgrade and act through a wide variety of mechanisms. This review investigated the main compounds with antifungal and anti-aflatoxigenic activity, also elucidating their physiological role and the different modes of action and synergies. Plant bioactive compounds are shown to be effective in modulating Aspergillus spp. contamination and AF production both in vitro and in vivo. Therefore, their application in pre- and postharvest management could represent an important tool to control aflatoxigenic fungi and to reduce AF contamination.

Keywords: Aspergillus, aflatoxins, reduction, bioactive compounds, plant extracts

\section{INTRODUCTION}

Aflatoxins (AFs) are toxic secondary metabolites, mainly produced by Aspergillus spp., which are recognized as human carcinogens (AFs of the B and $\mathrm{G}$ series) and possible carcinogens (AFs of the M series). They represent a great health concern (Kumar et al., 2017). Toxic outcomes, also known as aflatoxicosis, may include liver cancer, hepatotoxicity, immune system depression, and impaired growth both in humans and animals (IARC, 2012). AF maximum limits are regulated in Europe; products exceeding the maximum levels cannot be placed on the market nor mixed with uncontaminated ones (European Commission, 2006). From a chemical point of view, AFs (Figure 1) are difuranocoumarins composed of two furan rings arranged to a coumarin moiety in a rigid and planar structure (Loi et al., 2017). The high chemical stability endows them with high resistance to heat treatments, extreme $\mathrm{pH}$ values, high pressures, and mild (food grade) chemical treatments. As a result, the contamination persists in processed products, including those deriving from animals. Meat, milk, and eggs may also be contaminated with 
AF metabolites, mainly originating from in vivo hydroxylation reactions ( $A F$ of the series $M$, aflatoxicol, aflatoxin $Q_{1}$, and aflatoxin $\mathrm{P}_{1}$ ). AF contamination is a major problem in tropical and subtropical regions, where the environmental conditions are extremely favorable to fungal growth and AF production. However, in the last years, also Mediterranean areas have suffered from severe AF contamination due to climate change, temperature rise, and recurrent droughts (Moretti et al., 2019). AF management is a complex task, requiring actions at every stage of the supply chain (Figure 2). The application of the Good Manufacturing Practices (GAPs), i.e., crop rotation, the use of fungicides, and resistant varieties, is the first critical practice to prevent and reduce fungal contamination. However, the GAPs alone are not sufficient to avoid AF contamination, as it may depend upon several biotic and abiotic factors, also during storage (Mahuku et al., 2019). Therefore, the postharvest management is essential to manage AF contamination throughout the whole supply chain (Leslie and Logrieco, 2014).

Aspergillus spp. contamination can be detected in samples by several approaches. A basic microbiological diagnosis with chromogenic substrates was developed for the detection of toxigenic fungi, including Aspergillus flavus, Aspergillus carbonarius, and Aspergillus ochraceus. The great advantage is the use of basic laboratory equipment, a relatively low cost, and time for analysis (48-72 h). However, being a very generic growth test, it can be used only as a rapid screening test (Jefremova et al., 2016). On the contrary, advanced molecular PCR-based tools can be used to tackle conserved genes in Aspergillus spp. and AF biosynthetic gene cluster in contaminated materials (Moretti and Susca, 2017).

Controlling humidity, temperature, and moisture are among the most effective management strategies to cope with fungal spoilage and AF production during the storage and transport of susceptible commodities (Neme and Mohammed, 2017). Physical methods, such as sorting, dehulling, cleaning, and milling, are widely used to remove highly contaminated fractions from cereals during processing. Other physical methods include the use of microwave, UV, pulsed light, electrolyzed water, cold plasma, ozone, and irradiation. Despite their potentialities, their use is still limited due to the high technology cost and the residual toxic potential (Mahato et al., 2019).

Biological methods rely on the application of microorganisms (Liuzzi et al., 2017), pure enzymes (Loi et al., 2018), or enzyme extracts (Branà et al., 2020) able to degrade and, possibly, detoxify mycotoxins. In Europe, they can be authorized as postharvest treatments in feed, as long as safety, efficacy, and non-interference with feed nutrients is proved (Commission Regulation (EU) 2015/786, 2015).

The use of chemicals to prevent fungal growth in the field, in food, and feed products is a common practice worldwide. The use of fungicides and artificial preservatives has raised concern in consumers, researchers, and stakeholders because of the possible residual toxicity, carcinogenicity, and environmental pollution. The possible development of new resistant fungal strains is also a matter of great concern. Therefore, the use of natural compounds may encounter higher consumers' and stakeholders' acceptability
(Onaran and Yanar, 2016). Bioactive compounds deriving from plant metabolism belong to greatly diverse chemical groups and possess different biochemical and physiological roles. Therefore, they are considered versatile molecules. Indeed, determining the exact and univocal function of secondary metabolites in plants is a difficult task.

Nonetheless, they share common antimicrobial (Bassolé and Juliani, 2012), antifungal (Tabassum and Vidyasagar, 2013), antioxidant properties (Miguel, 2010), and the capability of improving the postharvest management of vegetable crops (Sivakumar and Bautista-Baños, 2014). Moreover, particular attention is paid to these molecules as bioactive compounds in the human diet because of their high antioxidative capacity (Pisoschi et al., 2016).

Despite their potentialities having been widely investigated in the past, their application as AFs control agents in pre- and postharvest remains still poorly explored. Bioactive compounds have been widely used to inhibit Aspergillus growth at different levels (mycelia growth, spore production, germ tube formation), to inhibit the secondary metabolism and AFs production. In addition, their direct use was also found to degrade AFs and, in some cases, detoxify them.

\section{BIOACTIVE COMPOUNDS IN PLANT METABOLISM}

Plants are the richest source of bioactive compounds. Bioactive metabolites are classified into primary or secondary metabolites, depending on their functional role (Sharma et al., 2019). Plants and fungi produce thousands of secondary metabolites according to the physiological stage, tissue localization (floral and nonfloral leaves, fruits, or bark), environmental conditions, and other biotic or abiotic stress. These compounds may be involved in the primary physiological function of the cell; they may participate in the control of cell growth and cell development, acting as plant growth substances, i.e., plant hormones. Among them, ethylene, auxin, gibberellins, abscisic acid, cytokinins, brassinosteroids, and polyamines are the most important ones (Depuydt et al., 2016). Nevertheless, their main function is ecological, especially with regards to the plant defense against herbivores, bacteria, and fungi (Mithöfer and Maffei, 2017).

Plants cope with pathogen attacks by different types of defense mechanisms, based on either anatomical or biochemical features (passive and constitutive defense), or active changes induced by pathogens (active and inducible defense). In some cases, like for terpenes, compounds can be secreted in low basal amounts constitutively, and expression can be triggered to produce higher amounts upon tissue damage or pathogen attack. Passive or constitutive defense compounds include glucosides, saponins, antifungal proteins, inhibitors of enzymes, and antifeedants, while inducible molecules include phytoalexins, pathogen-related (PR) proteins, chitinases, and glucanases (Walters, 2011).

Metabolites involved in the defense mechanism may occur in glycosylated or conjugated forms, which allow the plant to synthetize and store them in a non-toxic form. The conjugation or their specific localization (i.e., in the vacuoles or other 
<smiles>COC1=CC2OC3OC=CC3C2c2oc(=O)c3c(c21)CCC3=O</smiles>

Aflatoxin $\mathrm{B}_{1}$<smiles>COC1=CC2OC3OCCC3C2c2oc(=O)c3c(c21)CCC3=O</smiles>

Aflatoxin $\mathrm{B}_{2}$<smiles>COC1=CC2OC3OC=CC3C2c2oc(=O)c3c(c21)CCOC3=O</smiles>

Aflatoxin $\mathrm{G}_{1}$<smiles>COC1=CC2OC3OCCC3C2c2oc(=O)c3c(c21)CCOC3=O</smiles>

Aflatoxin $\mathrm{G}_{2}$<smiles>COC1=CC2OC3OC=CC3(O)C2c2oc(=O)c3c(c21)CCC3=O</smiles>

Aflatoxin $\mathrm{M}_{1}$<smiles>COC1=CC2OC3OC=CC3C2c2oc(=O)c3c(c21)C(O)CC3=O</smiles>

Aflatoxin $\mathrm{Q}_{1}$<smiles>COC1=CC2OC3OC=CC3C2c2oc(=O)c3c(c21)CCC3O</smiles>

Aflatoxicol<smiles>O=C1CCc2c3c(oc(=O)c21)C1C(C=C3O)OC2OC=CC21</smiles>

Aflatoxin $\mathrm{P}_{1}$

FIGURE 1 | Chemical structure of aflatoxins and their metabolites.

subcellular compartments) are strategies to avoid autoallelopathy and to produce active forms quickly and only when needed (Chaves Lobón et al., 2019).

Conversely, the de novo synthesis of antifungal molecules is also observed during the infection process in many plants. These substances are called phytoalexins, and they are similar to the constitutive antifungal toxins, although they show a more lipophilic character. Plants can also produce compounds with animal hormonal activity, the phytoecdysones, which can alter or cause precocious insect development. Finally, they may have a role in establishing the symbiotic processes with beneficial fungi and lichens (Ghasemzadeh and Ghasemzadeh, 2011).

Bioactive compounds can be extracted by different techniques: Soxhlet extraction, maceration, and hydrodistillation are

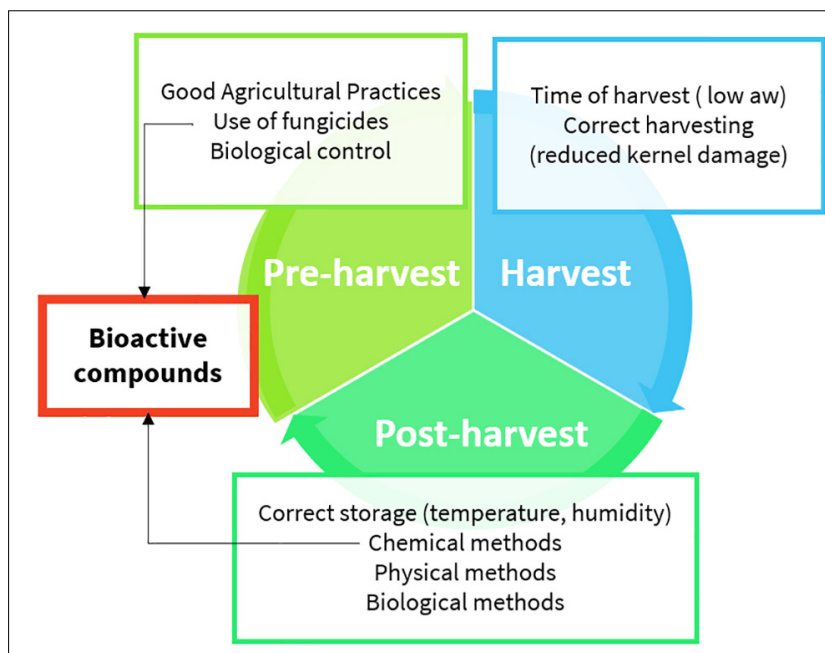

FIGURE 2 | Aflatoxin management practices (details are provided in the text). classically used. The use of ultrasounds, microwaves, electric fields, high pressures, or supercritical fluids have been investigated to reduce the use of solvents and apply gentler extraction conditions (Azmir et al., 2013; Giacometti et al., 2018). Water traces can be removed to obtain a concentrated extract, also referred as to essential oil (EO). On the basis of the biosynthetic origin, secondary metabolites can be divided into three main groups: (i) phenolics, (ii) terpenes, and (iii) nitrogencontaining compounds. With regards to the antifungal and antiaflatoxin activity, the most important bioactive secondary compounds are reported in Figure 3.

\section{(i) Phenolic Compounds}

The term phenolic compounds generally includes compounds bearing one or more hydroxylated aromatic rings and are subgrouped into phenolic acids, stilbenes, flavonoids, lignans, and ellargic acids. The flavonoids subgroup comprises a wide variety of simple compounds like anthocyanins, flavonols, chalcones, flavanones, flavones, and isoflavones or complex ones, such as condensed tannins (Zhang and Tsao, 2016). Thanks to their hydroxyl and carboxyl moieties, polyphenols act as antioxidants. They modulate the cellular redox status by directly quenching free radicals and chelating metal ions (promotors of oxidative reactions). They also activate redox-sensitive transcription factors for the antioxidative enzymes (superoxide dismutase, catalase, and glutathione peroxidase) (Upadhyay and Dixit, 2015). Protein binding and inhibition is mediated by hydrogen bonds between hydroxyl moiety of phenols and the carboxyl and thiol groups of proteins. Conversely, the aromatic ring is able to interact with proteins through van der Waals (hydrophobic) interaction.

Structure-activity relationships of two phenol derivatives (cinnamaldehyde and eugenol) were studied on two phytopathogenic fungi, namely, Rhizoctonia solani and 
A<smiles>C=CCc1ccc(O)c(OC)c1</smiles>

C<smiles>N#CS</smiles>

Thiocyanate

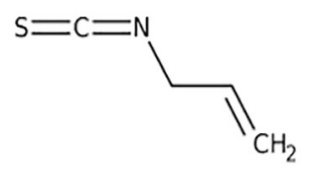

Allyl isothiocyanate
B<smiles>Cc1ccc(C(C)C)c(O)c1</smiles>

Thymol<smiles>Cc1ccc(C(C)C)cc1</smiles>

p-cymene<smiles>C=C(C)C1C=CC(C)CC1</smiles>

Limonene

FIGURE 3 | Chemical structure of the most important bioactive secondary compounds with antifungal and antiaflatoxin activity. (A) Phenols, (B) Terpenes, (C) N-containing compounds.

Fusarium oxysporum. Phenol antifungal activity was shown to depend on the chemical structure. In particular, aldehydes, acid groups, conjugated double bonds, and the length of $\mathrm{CH}$ chain outside the ring have increased the antifungal activity (Xie et al., 2017). While aldehydes and acid groups may be more prone to react with amino acid residues of proteins through hydrogen bonds and induce conformational modification because of the proton release ability, the length of the $\mathrm{CH}$ chain increases hydrophobicity, a major determinant of phenol capability to enter the plasma membrane (Ben Arfa et al., 2006; Dambolena et al., 2011).

\section{(ii) Terpenes}

Terpenes are volatile compounds deriving from the condensation of two or more isoprene molecules. They represent the largest class of plant compounds, with more than 40,000 different chemical structures. They are usually synthetized and stored in trichomes or secretory glands to be secreted constitutively or released as a consequence of tissue damages. Their function in plant metabolism is extremely diverse. Terpenes act as radical scavenging molecules against UV light damage and other environmental stresses. The double bonds can absorb high-energy radiation or scavenge free radicals, functioning as a first defense mechanism. Nonetheless, not all terpenes have a defensive function. Volatile terpenes are generally released constitutively to act as attractants to pollinators and symbionts, repellents to herbivores, or as signaling molecules to other plants or plant tissues. Polyisoprene intermediates are used in the post-translational modification of prenylated proteins (Pichersky and Raguso, 2018). Limonene, carvone, carvacrol, linalool, thymol, terpineol, myrcene, linalool, and pinene are the most important ones, with regards to the antifungal activity against Aspergillus spp. The latter activity is mainly due to their lipophilic nature, which allows them to enter the cell and interact with the cellular and mitochondrial membranes, and cause alteration in cell permeability and electrochemical potential (Tian et al., 2012b).

\section{(iii) Nitrogen-Containing Compounds}

Nitrogen-containing compounds are a heterogeneous group, which share the presence of at least one nitrogen atom in their chemical structure: glucosinolates, alkaloids, and cyanogenic glucosides are the main classes. All of them have defensive functions, but only glucosinolates have been recently exploited as antifungal and antiaflatoxin agents (Kaur et al., 2011).

With this regard, volatile compounds from Brussels sprouts (Brassica oleracea L. var. gemmifera DC.), cabbage (Brassica oleracea L.), kale (Brassica oleracea var. sabellica), radish (Raphanus sativus L.), and broccoli (Brassica oleracea L. var. botrytis L.) were extensively studied. Among them, the most important one is ally-l-isothiocyanate, a $\beta$-thioglycoside formed after the hydrolysis of glucosinolates by the enzyme myrosinase (Kumar et al., 2019). Hydrolysis occurs upon tissue damage, since glucosinolates are safely stored in the vacuole. Nitriles may be also produced as secondary products of the reaction. Thiocyanates and nitriles are hydrophilic compounds with high antioxidant capacity. They participate in plant defense systems as allelochemicals, volatile repellents, in the transcriptional regulation of the heat stress response, sulfur metabolism, water transport, stomatal opening, cell growth, and apoptosis (Bones et al., 2015). The isothiocyanate group $(-\mathrm{N}=\mathrm{C}=\mathrm{S})$ is highly nucleophilic and able to bind thiols, amino groups of amino acids, peptides, and proteins. The antifungal and antiaflatoxin properties are mainly due to the inactivation of crucial enzymes, such as reductases, acetate kinases, and oxidases (Nazareth et al., 2016).

\section{ANTIFUNGAL ACTIVITY OF BIOACTIVE COMPOUNDS}

Natural plant extracts have been widely used since ancient times for their antimicrobial activity against insects, bacteria, and fungi (Bakkali et al., 2008). Many of them are already 
employed as pharmaceuticals, feed and food additives, cosmetics and perfume ingredients because of their antioxidant capacity and strong organoleptic properties. Recently, their composition and biological activity have been investigated in relation to the antifungal activity and the ability to inhibit AF production by Aspergillus spp.

Carvacrol (Gómez et al., 2018), cinnamaldehyde (Bang et al., 2000; Xie et al., 2004; Tian et al., 2012b; Sun et al., 2016; Khorasani et al., 2017; Gómez et al., 2018), eugenol (Khorasani et al., 2017), limonene (Sharma and Tripathi, 2008; Rammanee and Hongpattarakere, 2011), p-cymene (Pinto et al., 2013), terpineol (Tian et al., 2012b; Kohiyama et al., 2015), thymol (Marei et al., 2012; Gorran et al., 2013; Kohiyama et al., 2015; Shen et al., 2016), and turmerone (Ferreira et al., 2013) are the main active compounds of cinnamon (Cinnamomum verum J. Presl), clove [Syzygium aromaticum (L.) Merr \& L.M. Perry], lemon [Citrus $\times$ limon (L.) Burm. f.], oregano (Origanum vulgare L.), and thyme (Thymus vulgaris L.) extracts. Their structure is shown in Figure 2, and the main effects as antifungal agents in plant extracts or as pure compounds are presented in Tables $1 \mathrm{~A}$ and $\mathbf{1 B}$, respectively.

Those compounds generally act synergistically and in a dosedependent manner. The highest effects were registered using increasing amounts of bioactive compounds and the whole EOs instead of single compounds (Tian et al., 2012a; Ferreira et al., 2013; Pinto et al., 2013).

Plant extracts are very complex mixtures, and their composition varies according to plant species and chemotype, phenological stage, tissue, and method of extraction (Figueiredo et al., 2008). Accordingly, their effect often has multiple targets (Figure 4) and different modes of action (Figure 5). They induce cytotoxicity through multiple pathways: (i) disrupting cell membrane permeability and functionality; (ii) inhibiting enzymes involved in the synthesis of cell wall components; (iii) impairing ergosterol metabolism; (iv) inducing ultrastructural alterations in cell compartments leading to swelling, vacuolations, and cation leakage; (v) inhibiting cytoplasmic and mitochondrial enzymes; and (vi) altering the osmotic and the redox balance.

\section{Effects on Cell Wall and Cell Membrane}

Fungal cell wall is a dynamic component, essential to assure cell viability. Moreover, it is involved in multiple cell functions, including morphogenesis and pathogenesis. Chitin, glucans, and pectins are the major building blocks, and they are continuously remodeled to cope with cell growth and differentiation by enzymes, such as chitin and glucan synthases, glycohydrolases, and transglycosidases (Gow et al., 2017). Therefore, these enzymes are perfect physiological targets to inhibit fungal growth.

An extensive survey on the antifungal activity of 13 different commercially available monoterpenes was performed by Marei et al. (2012). Among all tested compounds, thymol, followed by limonene, had the highest inhibitory effect on cellulase and pectin methyl esterase enzymes of Aspergillus niger, $F$. oxysporum, and Penicillium digitatum. The rate of inhibition on $A$. niger was higher for the pectin methyl esterase $\left(\mathrm{IC}_{50}\right.$ at $1.28 \mathrm{mg} \mathrm{L}^{-1}$ ) rather than for the cellulase ( $\mathrm{IC}_{50}$ at $44.56 \mathrm{mg} \mathrm{L}^{-1}$ ). Cinnamaldehyde was found to be a noncompetitive inhibitor of chitin synthase $\left(\mathrm{IC}_{50}\right.$ at $111.0 \mathrm{mg}$ $\left.\mathrm{L}^{-1}\right)$ and $b$-(1,3)-glucan synthase $\left(\mathrm{IC}_{50}\right.$ at $\left.190.3 \mathrm{mg} \mathrm{L}^{-1}\right)$ (Bang et al., 2000).

Ergosterol is the main sterol derivative of fungi, and it is essential to preserve cell membrane functionality as cholesterol does in animal cells. In addition, it is essential to ensure the activity of membrane-bound enzymes. Owing to its essential role in fungal cells, many fungicides act by inhibiting its biosynthesis or binding it in the cell membrane (Sant et al., 2016). Phenols and aldehydes possess a sufficient hydrophobicity to pass the double phospholipid bilayer, to interact with ergosterol in the cell membrane, or to enter the nucleus and act as regulators for its biosynthesis. As a consequence, alteration of fatty acid profiles along with modification of cell membrane, osmotic imbalance leading to irreversible damage of the hyphae membranes, conidiophores, and death occur (Ansari et al., 2013).

Cinnamomum spp. EO or its main component, cinnamaldehyde, were reported to impair ergosterol biosynthesis at concentrations as low as $2 \mathrm{mg} \mathrm{L}^{-1}$ (Tian et al., 2012b) and to cause irreversible deleterious morphological and ultrastructural degenerative alterations of the fungal cell membrane at $104 \mathrm{mg}$ $\mathrm{L}^{-1}$ (Sun et al., 2016; Khorasani et al., 2017). The same effect on fungal morphology was described for Thymus vulgaris L. (at 2,500 $\mathrm{mg} \mathrm{L}^{-1}$ ) (Kohiyama et al., 2015), Curcuma longa L. (Ferreira et al., 2013; Hu et al., 2014, 2017), and Anethum graveolens L. EOs (at 2 and $100 \mathrm{mg} \mathrm{L}^{-1}$ in vitro and in cherry tomatoes, respectively) (Tian et al., 2011).

Ergosterol biosynthesis may be regulated at the genomic level. Downregulation of ERG7, ERG11, ERG6, ERG3, and ERG5 genes by citral, the major component of lemongrass EO, was indeed reported for $P$. digitatum (OuYang et al., 2016).

\section{Mitochondrial Dysfunction}

Mitochondrial membrane potential is maintained in healthy cells by an electrochemical gradient through the electron transport chain, which is, ultimately, the major source of ATP molecules. As ATP levels decrease, the normal metabolic functions slow down until cell death occurs. The mechanism of action is not clearly understood. Several hypotheses have been made, including a direct inhibition of ATPases (see Enzyme Inhibition) and disruption of the osmotic balance, mainly causing calcium and protons leaking and, consequently, of the electrochemical potential. As for polygodial, a naturally occurring sesquiterpene dialdehyde isolated from different plant species, the mechanism was studied in depth, although with mammalian mitochondrial preparations. In this case, direct inhibition of enzymes was excluded. Indeed, the mechanism was supposed to rely on the uncoupling of the mitochondrial ATPase due to the modification of the electric properties of the membrane surface (Castelli et al., 2005). In yeasts, carvacrol was also responsible for the induction of calcium stress, mediated by the activation of specific intracellular signaling pathways (Rao et al., 2010). 
TABLE 1A | Antifungal activity of plant extracts on Aspergillus spp.

\begin{tabular}{|c|c|c|c|c|c|}
\hline Plant/compounds & Type of extract or oils & Major components & Antifungal activity & $\begin{array}{l}\text { Concentration of } \\
\text { active } \\
\text { compound(s) (mg } \\
\left.\mathrm{L}^{-1} \text { or } \mathrm{ml} \mathrm{L}^{-1}\right)\end{array}$ & References \\
\hline Jojoba oil & & Gadoleic acid, erucic acid & $\begin{array}{l}\text { Growth inhibition of Aspergillus } \\
\text { parasiticus, A. ochraceus, Fusarium } \\
\text { solani, Penicillium sp. }\end{array}$ & n.p. & $\begin{array}{l}\text { Badr et al. } \\
\text { (2017) }\end{array}$ \\
\hline Jojoba pomace extract & $\begin{array}{l}\text { Aqueous isopropyl extract, } \mathrm{pH} \\
4-5\end{array}$ & $\begin{array}{l}84.7 \% \text { phenols, } 15.3 \% \\
\text { flavonoids }\end{array}$ & & & \\
\hline Jatropha oil & & Linoleic acid, oleic acid & & & \\
\hline Jatropha pomace extract & $\begin{array}{l}\text { Aqueous isopropyl extract, } \mathrm{pH} \\
4-5\end{array}$ & $\begin{array}{l}78.4 \% \text { phenols, } 21.6 \% \\
\text { flavonoids }\end{array}$ & & & \\
\hline Mentha (Mentha pulegium L.) & Aqueous extract & n.p. & Growth inhibition of $A$. flavus & 8,000 & $\begin{array}{l}\text { Omidpanah } \\
\text { et al. (2015) }\end{array}$ \\
\hline Senna (Cassia senna L.) & & & & 6000 & \\
\hline Basil (Ocimum basilicum L.) & & & & 8,000 & \\
\hline Thyme (Thymus vulgaris L.) & & & & 2,000 & \\
\hline $\begin{array}{l}\text { Safflower (Carthamus tinctorius } \\
\text { L.) }\end{array}$ & & & & 4,000 & \\
\hline Hairy cistus (Cistus incanus L.) & Methanolic extract & n.p. & $\begin{array}{l}\text { Growth inhibition of } A \text {. parasiticus; up } \\
\text { to } 90 \% \text { of reduction of } \text { AFB }_{1} \text { production } \\
\text { in YES medium and } 86 \% \text { in macadamia } \\
\text { nuts }\end{array}$ & n.p. & $\begin{array}{l}\text { Kalli et al. } \\
(2018)\end{array}$ \\
\hline $\begin{array}{l}\text { Cinnamon (Cinnamomum } \\
\text { zeglanicum Garcin ex Blume) }\end{array}$ & $\begin{array}{l}\text { Diluted water extract }(3,5,7 \text {, } \\
\text { and } 9 \% \mathrm{v} / \mathrm{v})\end{array}$ & $88.7 \%$ cinnamaldehyde & $\begin{array}{l}\text { Up to } 100 \% \text { growth inhibition of } \\
\text { Aspergillus flavus on PDA extract (using } \\
3 \% \text { extract after } 1 \text { day); } 100 \% \text { reduction } \\
\text { of } \mathrm{AFB}_{1} \text { production in pistachio nuts }\end{array}$ & n.p. & $\begin{array}{l}\text { Khorasani } \\
\text { et al. (2017) }\end{array}$ \\
\hline $\begin{array}{l}\text { Clove (Caryophyllus aromaticus } \\
\text { L.) }\end{array}$ & & $71.1 \%$ eugenol & & & \\
\hline $\begin{array}{l}\text { Thyme (Thymus daenensis } \\
\text { Celak) }\end{array}$ & & $\begin{array}{l}\text { Thymol }(73.9 \%) \text { and carvacrol } \\
(6.7 \%)\end{array}$ & $\begin{array}{l}\text { Up to } 100 \% \text { growth inhibition of } \\
\text { Aspergillus flavus on PDA extract (using } \\
7 \% \text { extract after } 1 \text { day); up to } 100 \% \\
\text { reduction of } \mathrm{AFB}_{1} \text { production in } \\
\text { pistachio nuts }\end{array}$ & & \\
\hline Oregano (Origanum vulgare L.) & $\begin{array}{l}\text { Commercially available } \\
\text { essential oil }\end{array}$ & $86 \%$ carvacrol & $\begin{array}{l}\text { Growth inhibition of } A \text {. parasiticus and } \\
\text { A. flavus in maize extract medium } \\
\text { under different environmental } \\
\text { conditions }\left(25-37^{\circ} \mathrm{C} \text {, aw } 0.99-0.96\right)\end{array}$ & $152-505$ & $\begin{array}{l}\text { Gómez } \\
\text { et al. (2018) }\end{array}$ \\
\hline $\begin{array}{l}\text { Cinnamon (Cinnamomum } \\
\text { verum J. Presl) }\end{array}$ & & $66.5 \%$ cinnamaldehyde & & $295-675$ & \\
\hline
\end{tabular}


TABLE 1A | Continued

Plant/compounds

Type of extract or oils

Major components

Antifungal activity

Concentration of active

ompound(s) (mg

$\mathrm{L}^{-1}$ or $\mathrm{ml} \mathrm{L}^{-1}$ )

Cinnamon (Cinnamomum

jensenianum Hand.-Mazz.)

Dill (Anethum graveolens L.)

EO obtained by hydrodistillation

$17.3 \%$ eucalyptol, $12.5 \%$

$\alpha$-terpineol

n.p.

Dill (Anethum graveolens L.)

EO obtained by hydrodistillation

EO obtained by hydrodistillation

Thyme (Thymus vulgaris $\mathrm{L}$.)

Thyme (Thymus daenensis

Celak)

Hydrodistillates resuspended in ethano

Savory (Satureja khuzestanica) Savory (Satureja macrosiphonia Bornm)

Turmeric (Curcuma longa L.)

Turmeric (Curcuma longa L.)

Ferula (Ferulago capillaris Link ex Spreng.)

n.p., not provided.
EO obtained by hydrodistillation

Hydrodistillates resuspended in 5\% (v/v) Tween-20

EO obtained by hydrodistillation
$40.6 \%$ borneol, $19.9 \%$ $\alpha$-terpineol, $12.3 \%$ camphene

n.p.

Oxygenated sesquiterpenes

(60.7\%) Sesquiterpene

hydrocarbons (34.3\%)

ar-turmerone (33.2\%)

$\alpha$-turmerone $(23.5 \%)$

B-turmerone (22.7\%)

$\alpha$-Pinene (35.8\%) and limonene (30.9\%)
Growth inhibition of $A$. flavus, A. oryzae,

A. niger; up to $100 \%$ of reduction of

$\mathrm{AFB}_{1}$ production

Growth inhibition of $A$. flavus by

disruption of mitochondrial membrane potential (MMP), acidification of external medium, and mitochondrial ATPase

and dehydrogenase activities

100\% growth inhibition of Aspergillus spp.

Up to 86.1 and $94.4 \%$ growth inhibition of Aspergillus spp. in healthy and

wounded cherry tomatoes, respectively

Growth inhibition of $A$. flavus, up to

$100 \%$ of reduction of $\mathrm{AFB}_{1}$ production

Mycelial growth and spore production inhibition of $A$. flavus, up to $100 \%$ of reduction of $\mathrm{AFB}_{1}$ production

Mycelial growth and spore production inhibition of $A$. flavus, up to $56.8 \%$ of reduction of $\mathrm{AFB}_{1}$ production

Up to: $93.41 \%$ mycelial growth

inhibition; $93.41 \%$ spore germination

inhibition; $74.6 \%$ activity inhibition of

mitochondrial ATPase and $84.7 \%$

dehydrogenases activity inhibition

Up to $99.0 \%$ inhibition of AFB

production using $5 \%(W / W)$ of extract

2 (in vitro)-120

(in vivo)

Tian et a

$25-2,000$

Tian et al.

(2012a)

ian et al.

(2011)

100

1,500 (for $\mathrm{AFB}_{1}$

reduction); 2,500 et al. (2015)

(for $A$. flavus growth

inhibition)

350

Gorran

et al. (2013)

500

n.p.

Hu et al.

(2014)

Inhibition of Aspergillus spp. growth 
TABLE 1B | Antifungal activity of pure commercial compounds on Aspergillus spp.

\begin{tabular}{|c|c|c|c|}
\hline Plant/compounds & Antifungal activity & $\begin{array}{l}\text { Concentration of active } \\
\text { compound(s) }\left(\mathrm{mg} \mathrm{L}^{-1} \text { or } \mathrm{ml} \mathrm{L}^{-1}\right)\end{array}$ & References \\
\hline Isothiocyanate & $\begin{array}{l}\text { Up to } 100 \% \text { of inhibition of } A \text {. parasiticus growth and } \\
\text { aflatoxin production }\end{array}$ & 0.01 & Nazareth et al. (2016) \\
\hline Isothiocyanate & Corn kernels & $\geq 0.00005$ & Tracz et al. (2017) \\
\hline Allyl isothiocyanate & $\begin{array}{l}\text { Inhibition of } A \text {. flavus growth and aflatoxin production in } \\
\text { corn, barley, and wheat in simulated silo system }\end{array}$ & 0.0005 & Quiles et al. (2015) \\
\hline Allyl isothiocyanate & $\begin{array}{l}\text { Inhibition of Aspergillus parasiticus growth and aflatoxin } \\
\text { production in Brazil nuts }\end{array}$ & 0.0000025 & Lopes et al. (2018) \\
\hline Curcumin & $\begin{array}{l}\text { Up to } 96.0 \% \text { inhibition of } \mathrm{AFB}_{1} \text { production using } 0.5 \% \\
(w / w) \text { of extract }\end{array}$ & n.p. & Ferreira et al. (2013) \\
\hline Cinnamaldehyde & $\begin{array}{l}\text { Inhibition of radial growth, spore, and aflatoxin } \\
\text { production of } A \text {. flavus }\end{array}$ & 104 & Sun et al. (2016) \\
\hline Camphene & \multirow{13}{*}{$\begin{array}{l}\text { Mycelial growth inhibition of } F \text {. oxysporum, A niger, } P \text {. } \\
\text { digitatum; inhibition of pectin methyl esterase, cellulase, } \\
\text { and polyphenol oxidase enzymes }\end{array}$} & From 121.5 to 314.2 & Marei et al. (2012) \\
\hline (R)-Camphor & & From 157.1 to 367.0 & \\
\hline (R)-Carvone & & From 432.5 to 120.0 & \\
\hline 1,8-Cineole & & From 36.4 to 148.4 & \\
\hline Cuminaldehyde & & From 79.5 to 363.5 & \\
\hline (S)-Fenchone & & From 193.8 to 330.6 & \\
\hline Geraniol & & From 73.9 to 357.0 & \\
\hline Carbendazim & & From 13.6 to 37.38 & \\
\hline (R)-Linalool & & From 266.6 to 73.7 & \\
\hline (1R,2S,5R)-Menthol & & From 121.9 to 394.4 & \\
\hline Myrcene & & From 95.5 to 336.9 & \\
\hline Thymol & & From 20.1 to 50.4 & \\
\hline (S)-Limonene & & From 26.8 to 153.2 & \\
\hline
\end{tabular}

n.p., not provided.

\section{Enzyme Inhibition}

Mitochondrial dysfunction may also occur via ATPase inhibition. Dill (Anethum graveolens L.) EO was shown to affect mitochondrial and plasma membrane ATPase at 0.08-0.64 $\mathrm{ml} \mathrm{L}^{-1}$ (Pinto et al., 2013), while turmeric (C. longa L.) EO was shown to suppress mitochondrial dehydrogenases and mitochondrial ATPase at $2-8 \mathrm{ml} \mathrm{L}^{-1}$ (Hu et al., 2014). Turmeric EO was also found to exert antifungal activity via ATPase, malate dehydrogenase, and succinate dehydrogenase inhibition at $1-8 \mathrm{ml} \mathrm{L}^{-1}$ in vitro and $4 \mathrm{ml} \mathrm{L}^{-1}$ in maize ( $\mathrm{Hu}$ et al., 2017). The reactivity of phenols and aldehydes in EOs to proteins and enzymes is the major mechanism, as reported for isothiocyanates.

Isothiocyanate were successfully used to inhibit Aspergillus parasiticus in vitro at doses of $5 \mathrm{mg}$ (Manyes et al., 2015) or even in gaseous form in foods at concentrations of $100.01 \mathrm{ml}$ $\mathrm{L}^{-1}$ in wheat flour (Nazareth et al., 2016), at $\geq 0.05 \mathrm{ml} \mathrm{L}^{-1}$ in corn kernels (Tracz et al., 2017), at $0.5 \mathrm{ml} \mathrm{L}^{-1}$ in corn, barley, and wheat in simulated silo system (Quiles et al., 2019), at $0.0025 \mathrm{ml} \mathrm{L}^{-1}$ in Brazil nuts (Lopes et al., 2018), and at 46,040 and $78,250 \mathrm{mg} / \mathrm{kg}$ in the Italian "piadina" (Saladino et al., 2016).

\section{INHIBITORY EFFECT ON AFLATOXIN $B_{1}$ PRODUCTION}

Aflatoxins are polyketide-derived furanocoumarins, the production of which depends upon 25 different genes, clustered together in a 70-kb DNA sequence region. The majority of the genes encodes for enzymes involved in the synthesis and participates as transcription factors, while others do not have a clear assigned function (Yu et al., 2004).

Many physiological events in fungal cells are regulated by oxidative bursts such as differentiation, switch from conidia to germ tube development, and the onset of secondary metabolism. In particular, oxidants are able to induce AF biosynthesis (Reverberi et al., 2006). In the presence of oxidative stress, the fungal antioxidant molecules (tocopherols, ascorbic acid, carotene, reduced glutathione) and enzymes (superoxide dismutase, catalase, and glutathione peroxidase) are induced concomitantly to $\mathrm{AF}$ biosynthetic gene cluster (Reverberi et al., 2010). Therefore, it was also suggested that AF production may also be a way to incorporate oxygen atoms and protect cells from oxidative damage (Kim et al., 2005). The mechanism of EOs or their components may be associated with their antioxidant activity, responsible for the attenuation of the fungal oxidative stress responses, thus AF production (Kim et al., 2005; Reverberi et al., 2005).

Different compounds have been proven to inhibit the production of secondary metabolites like $\mathrm{AFB}_{1}$, at comparable or slightly lower concentrations than those that inhibit the mycelial growth, which is consistent with their supposed mode of action. The different inhibition pattern suggests that the suppressive effect is elicited 


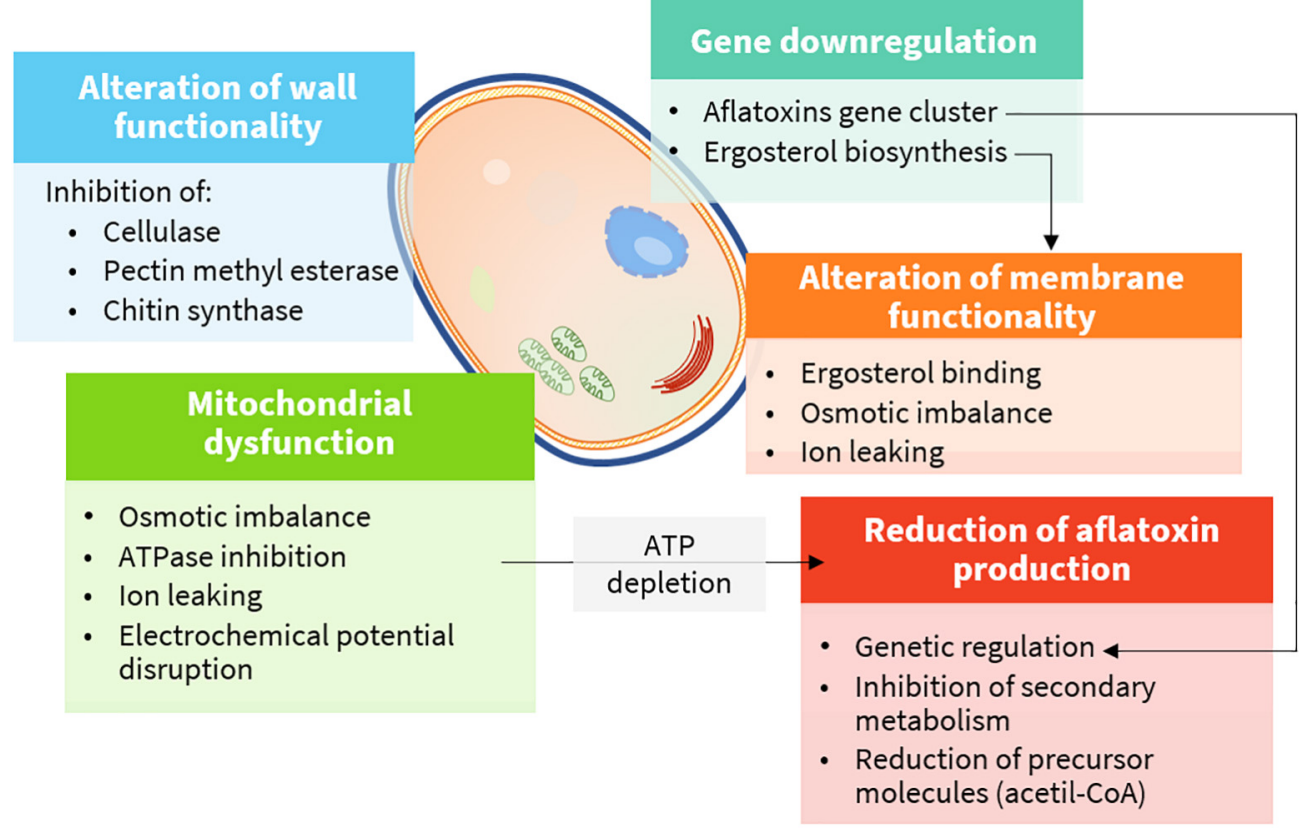

FIGURE 4 | Cellular targets and mechanisms of action of bioactive compounds (details are provided in the text).

\section{Phenols}

- Hydrogen bonds with carboxyl and thiol groups of proteins

- Van der Waals interaction with hydrophobic amino acid residues

- Interaction with cell membrane and ergosterol due to lipophilic character of the aromatic ring

\section{Terpenes}

Interaction with the cell and mitochondrial membranes due to lipophilic nature

\section{$\mathrm{N}$-containing compounds}

- Covalent bond with thiols and amino groups of proteins of the nucleophilic isothiocyanate group $(-\mathrm{N}=\mathrm{C}=\mathrm{S})$

FIGURE 5 | Functional groups and mode of action of bioactive compounds.

on transcriptional regulators (AflR and AflS) as well as on structural genes (Georgianna and Payne, 2009), as reported in Table 2 .

Eugenol was proved to be effective in downregulating aflM, aflD, aflC, aflP, aflR (Jahanshiri et al., 2015), aflP, aflM, aflD, and aflT (Liang et al., 2015; Lv et al., 2018) genes. Conversely, turmeric EO downregulated aflD, aflM, aflO, aflP, and aflQ genes (Hu et al., 2017). In a recent study by Moon et al. (2018) $\gamma$-terpinene was found to downregulate aflC, aflD, aflE, aflK, aflO, and aflQ genes, whereas citral downregulated aflD, aflE, aflK, aflL, aflO, aflQ, aflR, aflS, aflC, and aflG.

Finally, inhibition of the secondary metabolism as a consequence of the reduced fungal growth and ATP and AF precursor depletion (acetyl coenzyme A) by mitochondrial dysfunction may contribute to the general antiaflatoxigenic effect of these compounds (Tian et al., 2011).

\section{AFLATOXIN DEGRADATION ACTIVITY}

Various plant extracts were reported to degrade $\mathrm{AFB}_{1}$ as well as other mycotoxins both in vitro and in vivo, as reported in Table 3.

In most of the studies, the active agents were water soluble, belonged to the flavonoids and phenol groups. Besides the activity of those low molecular weight compounds, the possible coextraction of enzymes able to degrade mycotoxins has to be taken into account. In fact, a detrimental effect on the degrading activity was observed after boiling, while no effect was registered after dialysis with $10-14 \mathrm{kDa}$ cutoff membrane. This suggests that heat-sensitive, high-molecular weight compounds may play a significant role in AF degradation (Vijayanandraj et al., 2014; Ponzilacqua et al., 2019). Indeed, many enzymes, also belonging to plants, have been described for their ability to degrade AFs (Loi et al., 2017; Lyagin and Efremenko, 2019). Among them, polyphenol oxidases and laccases may also use low molecular weight compounds as redox mediators, thus enhancing their degradation capability through a synergistic or additive mechanism (Loi et al., 2018).

Although the mechanism of action is not clearly understood, some authors evaluated the outcome of the degradation 
TABLE 2 | Aflatoxins genes regulated by bioactive compounds.

\begin{tabular}{|c|c|c|}
\hline Gene & Function & $\begin{array}{l}\text { Bioactive compound and } \\
\text { references }\end{array}$ \\
\hline $\begin{array}{l}\text { aflC previously } \\
\text { known as pksA }\end{array}$ & Polyketide synthase & $\begin{array}{l}\text { Eugenol (Jahanshiri et al., 2015) } \\
\gamma \text {-terpinene (Moon et al., 2018) }\end{array}$ \\
\hline $\begin{array}{l}\text { aflD previously } \\
\text { known as nor-1 }\end{array}$ & Reductase & $\begin{array}{l}\text { Eugenol (Jahanshiri et al., } \\
\text { 2015; Liang et al., 2015; Lv } \\
\text { et al., 2018) Turmeric EO (Hu } \\
\text { et al., 2017) } \gamma \text {-terpinene and } \\
\text { citral (Moon et al., 2018) }\end{array}$ \\
\hline aflE & Reductase & $\gamma$-Terpinene (Moon et al., 2018) \\
\hline aflK & $\begin{array}{l}\text { Versicolorin } \\
\text { synthase }\end{array}$ & $\gamma$-Terpinene (Moon et al., 2018) \\
\hline aflL & Desaturase & Citral (Moon et al., 2018) \\
\hline aflM previously & Dehydrogenase/ & Eugenol (Jahanshiri et al., \\
\hline known as ver-1 & ketoreductase & $\begin{array}{l}\text { 2015; Liang et al., 2015; Lv } \\
\text { et al., 2018) Turmeric EO (Hu } \\
\text { et al., 2017) }\end{array}$ \\
\hline $\mathrm{aflO}$ & $\begin{array}{l}\text { Oxidoreductase/P450 } \\
\text { monooxygenase }\end{array}$ & $\begin{array}{l}\text { Turmeric EO (Hu et al., 2017) } \\
\gamma \text {-Terpinene and citral (Moon } \\
\text { et al., 2018) }\end{array}$ \\
\hline $\begin{array}{l}\text { aflP previously } \\
\text { known as omtA }\end{array}$ & Methyltransferase & $\begin{array}{l}\text { Eugenol (Jahanshiri et al., } \\
\text { 2015; Liang et al., 2015; Lv } \\
\text { et al., 2018) Turmeric EO (Hu } \\
\text { et al., 2017) }\end{array}$ \\
\hline aflQ & O-Methyltransferase & $\begin{array}{l}\gamma \text {-Terpinene (Moon et al., 2018) } \\
\text { Citral (Moon et al., 2018) }\end{array}$ \\
\hline aflR & $\begin{array}{l}\text { Transcriptional } \\
\text { regulator }\end{array}$ & $\begin{array}{l}\text { Eugenol (Jahanshiri et al., } 2015 \\
\text { Citral (Moon et al., 2018) }\end{array}$ \\
\hline aflS & $\begin{array}{l}\text { Transcription } \\
\text { enhancer }\end{array}$ & Citral (Moon et al., 2018) \\
\hline aflT & $\begin{array}{l}\text { Transmembrane } \\
\text { protein }\end{array}$ & $\begin{array}{l}\text { Eugenol (Liang et al., 2015; Lv } \\
\text { et al., 2018) }\end{array}$ \\
\hline
\end{tabular}

by high-performance liquid chromatography (HPLC) and liquid chromatography tandem MS (LC-MS/MS). The chemical properties of AFs were deeply modified upon incubation with plant extracts. $\mathrm{AFB}_{1}$ was modified in different ways, including the removal of the double bond of the furan ring and the modification of the lactone ring, resulting in a significant decrease in the cytotoxicity, evaluated on Hela cells (Velazhahan et al., 2010) and by Brine shrimps (Artemia salina) bioassay (Iram et al., 2015, 2016a,b). The toxic and carcinogenic potential of $\mathrm{AFB}_{1}$ was indeed attributed to the difuran ring, which in vivo is quickly oxidized to 8,9epoxy- $\mathrm{AFB}_{1}$ and, to a lesser extent, to the lactone moiety (Loi et al., 2016).

\section{DISCUSSION}

The use of natural compounds in pre- and postharvest appears appealing, especially when compared to the use of antibiotics or fungicides from synthetic origin. Natural flavoring compounds derived from plants were listed as GRAS compounds in Europe and the United States: among others, clove, marjoram, thyme, nutmeg, basil, mustard, and cinnamon. However, despite their proven in vitro efficacy and their GRAS status, the use of those compounds as a pre- or postharvest treatment has different limitations: high volatility, poor stability due to oxidation reactions, and strong organoleptic features. This latter may lead to unpleasant tastes and off-flavors in food and feed or interfere with the signaling pathway mechanisms mediated by volatile compounds in the field. To overcome these limitations, different technologies have been studied to deliver bioactive components while preserving them from unwanted chemical reactions and controlling the organoleptic impact. Emulsification, spray drying, coaxial electrospray system, freeze drying, coacervation, in situ polymerization, extrusion, fluidized bed coating, and supercritical fluid technology are the most promising ones (Bakry et al., 2016). EOs can be also incorporated in edible coatings (Peretto et al., 2014; Alotaibi et al., 2019), films (Giteru et al., 2015), or even sprayed on food in a vapor form (Gao et al., 2014).

Among the different proposed technologies, the encapsulation of EOs has many advantages, i.e., even dispersion and release of EOs, odor masking, increased shelf life, and improved technological properties (easy dosing and pouring, increased solubility, dust-free material) (Wu et al., 2012; da Rosa et al., 2015).

The antifungal activity of encapsulated eugenol, menthol, and t-anethole (Kumar et al., 2019), Illicium verum Hook. f. (Dwivedy et al., 2018), Cinnamomum zeylanicum Garcin ex Blume (Kiran et al., 2016), and Coriandrum sativum L. (Das et al., 2019). EOs was investigated in vitro toward A. flavus, and was shown to reduce $\mathrm{AFB}_{1}$ production with promising results. A recent study by Mateo et al. (2017) investigated the antiaflatoxigenic potential of a bioactive packaging based on ethylene-vinyl alcohol copolymer films incorporating EOs from O. vulgare L., C. zeylanicum Garcin ex Blume, or their major active constituents, carvacrol and cinnamaldehyde. On the contrary, the antifungal activity of allyl isothiocyanate was completely lost upon encapsulation (Janatova et al., 2015). This means that specific delivery systems have to be developed for each EO or bioactive compound.

Moreover, the effectiveness of the preharvest treatments also depends upon several biotic and abiotic factors. The treatment response may vary according to the specific plant species or cultivar, due to the activation of cultivar-specific defense pathways and different host-pathogen interaction patterns (Feliziani et al., 2015). Weather conditions and the phenological stage at the delivery may also affect the results of the treatment in the field.

Few in vivo trials were conducted to evaluate the efficacy of the use of natural compounds as antifungal agents, even though they focused on the reduction in the postharvest decay (Sivakumar and Bautista-Baños, 2014; Feliziani et al., 2015).

As regards the postharvest treatments, food matrix and composition, lipid content, water activity, $\mathrm{pH}$, and enzymes can decrease their effectiveness as an antimicrobial or antifungal compound (Hyldgaard et al., 2012). Therefore, with respect to the in vitro studies, $1-3 \%$ higher amounts may be needed to achieve the same results (Firouzi et al., 2007). Nonetheless, when high amounts are used, the organoleptic properties of the food may be impaired. To overcome this issue, lower concentrations 
TABLE 3 | Degradation activity of plant extract on aflatoxin $B_{1}\left(A_{F B}\right)$.

\begin{tabular}{|c|c|c|c|c|}
\hline Plant & $\begin{array}{l}\text { Type of } \\
\text { extract/oils }\end{array}$ & In vitro/in matrix $\mathrm{AFB}_{1}$ reduction & $\begin{array}{l}\text { Relative toxicity } \\
\text { of } \text { AFB }_{1} \\
\text { degradation } \\
\text { products }\end{array}$ & References \\
\hline $\begin{array}{l}\text { Araçá (Psidium } \\
\text { cattleianum) }\end{array}$ & Aqueous extract & $\begin{array}{l}\text { Up to } 30 \% \text { of } \mathrm{AFB}_{1} \text { degradation }(16.67 \mu \mathrm{g} / \mathrm{L}) \text { after } 48 \mathrm{~h} \text { of } \\
\text { incubation in aqueous medium, } \mathrm{pH} 6.0-7.0\end{array}$ & n.p. & $\begin{array}{l}\text { Ponzilacqua } \\
\text { et al. (2019) }\end{array}$ \\
\hline $\begin{array}{l}\text { Rosemary } \\
\text { (Rosmarinus } \\
\text { officinalis L.) }\end{array}$ & & $\begin{array}{l}\text { Up to } 60 \% \text { of } \mathrm{AFB}_{1} \text { degradation }(16.67 \mu \mathrm{g} / \mathrm{L}) \text { after } 48 \mathrm{~h} \text { of } \\
\text { incubation in aqueous medium, } \mathrm{pH} 6.0-7.0\end{array}$ & n.p. & \\
\hline $\begin{array}{l}\text { Oregano (Origanum } \\
\text { vulgare L.) }\end{array}$ & & $\begin{array}{l}\text { Up to } 38 \% \text { of } A_{F B} \text { degradation }(16.67 \mu \mathrm{g} / \mathrm{L}) \text { after } 48 \mathrm{~h} \text { of } \\
\text { incubation in aqueous medium, } \mathrm{pH} 6.0-7.0\end{array}$ & n.p. & \\
\hline \multirow[t]{2}{*}{$\begin{array}{l}\text { Basil (Ocimum } \\
\text { basilicum L.) }\end{array}$} & Aqueous extract & $\begin{array}{l}\text { Up to } 90 \% \text { of } \mathrm{AFB}_{1} \text { degradation }(100 \mu \mathrm{g} / \mathrm{L}) \text { after } 72 \mathrm{~h} \text { at } 60^{\circ} \mathrm{C} \\
\text { in aqueous extract; }\end{array}$ & $\begin{array}{l}70 \% \text { of mortality } \\
\text { reduction by Brine } \\
\text { shrimps (Artemia } \\
\text { salina) bioassay }\end{array}$ & $\begin{array}{l}\text { Iram et al. } \\
(2016 a)\end{array}$ \\
\hline & & $\begin{array}{l}\text { In matrix degradation (maize) up to } 90.4 \% \text { of degradation after } \\
72 \text { h of incubation at } 30^{\circ} \mathrm{C}, \mathrm{pH} 8\end{array}$ & & \\
\hline \multirow[t]{2}{*}{$\begin{array}{l}\text { Golden tree (Cassia } \\
\text { fistula L.) }\end{array}$} & & $\begin{array}{l}\text { Up to } 54 \% \text { of } A F B_{1} \text { degradation }(100 \mu \mathrm{g} / \mathrm{L}) \text { after } 72 \mathrm{~h} \text { at } 60^{\circ} \mathrm{C} \\
\text { in aqueous extract; }\end{array}$ & n.p. & \\
\hline & & $\begin{array}{l}\text { Up to } 62.5 \% \text { of } \mathrm{AFB}_{1} \text { degradation }(100 \mu \mathrm{g} / \mathrm{L} \text {, spiked }) \text { in maize } \\
\text { after } 72 \mathrm{~h} \text { of incubation at } 30^{\circ} \mathrm{C}, \mathrm{pH} 8\end{array}$ & & \\
\hline \multirow[t]{2}{*}{$\begin{array}{l}\text { Ajowan caraway } \\
\text { (Trachyspermum } \\
\text { ammi L.) Sprague } \\
\text { ex Turrill }\end{array}$} & Aqueous extract & $\begin{array}{l}\text { Up to } 92.8 \% \text { of } \mathrm{AFB}_{1} \text { degradation }(100 \mu \mathrm{g} / \mathrm{L}) \text { after } 72 \mathrm{~h} \text { of } \\
\text { incubation at } 30^{\circ} \mathrm{C}, \mathrm{pH} 8\end{array}$ & $\begin{array}{l}72 \% \text { of mortality } \\
\text { reduction by Brine } \\
\text { shrimps (Artemia } \\
\text { salina) bioassay }\end{array}$ & $\begin{array}{l}\text { Iram et al. } \\
(2016 b)\end{array}$ \\
\hline & & $\begin{array}{l}\text { Up to } 89.6 \% \text { of } \mathrm{AFB}_{1} \text { degradation }(100 \mu \mathrm{g} / \mathrm{L} \text {, spiked) in maize } \\
\text { after } 72 \mathrm{~h} \text { of incubation at } 30^{\circ} \mathrm{C}, \mathrm{pH} 8\end{array}$ & & \\
\hline \multirow[t]{2}{*}{$\begin{array}{l}\text { Lemon Scented } \\
\text { Eucalyptus } \\
\text { (Corymbia } \\
\text { citriodora) }\end{array}$} & $\begin{array}{l}\text { Leaf aqueous } \\
\text { extract }\end{array}$ & $\begin{array}{l}\text { Up to } 95.21 \% \text { of } \mathrm{AFB}_{1} \text { degradation }(100 \mu \mathrm{g} / \mathrm{L}) \text { after } 72 \mathrm{~h} \text { of } \\
\text { incubation at } 30^{\circ} \mathrm{C}, \mathrm{pH} 8 \text {; }\end{array}$ & $\begin{array}{l}75 \% \text { of mortality } \\
\text { reduction by Brine } \\
\text { shrimps (Artemia } \\
\text { salina) bioassay }\end{array}$ & $\begin{array}{l}\text { Iram et al. } \\
(2015)\end{array}$ \\
\hline & & $\begin{array}{l}\text { Up to } 70.26 \% \text { of } \mathrm{AFB}_{1} \text { degradation }(100 \mu \mathrm{g} / \mathrm{L} \text {, spiked) in maize } \\
\text { after } 72 \mathrm{~h} \text { of incubation at } 30^{\circ} \mathrm{C}, \mathrm{pH} 8\end{array}$ & & \\
\hline $\begin{array}{l}\text { Garlic (Allium } \\
\text { sativum L.) }\end{array}$ & Aqueous extracts & $\begin{array}{l}61.7 \% \text { of } \mathrm{AFB}_{1} \text { degradation }(50 \mu \mathrm{g} / \mathrm{L}) \text { after } 1 \mathrm{~h} \text { of incubation at } \\
37^{\circ} \mathrm{C} \text { in PBS medium; } 68.3 \% \text { after } 1 \mathrm{~h} \text { of incubation at } 37^{\circ} \mathrm{C} \text { in } \\
\text { real-contaminated sample using } 50 \mathrm{mg} / \mathrm{L} \text { of extract }\end{array}$ & n.p. & $\begin{array}{l}\text { Negera and } \\
\text { Washe (2019) }\end{array}$ \\
\hline $\begin{array}{l}\text { Lemon (Citrus } \\
\text { limon L.) }\end{array}$ & & $\begin{array}{l}56.0 \% \text { of } \mathrm{AFB}_{1} \text { degradation ( } 50 \mu \mathrm{g} / \mathrm{g} \text {, spiked) after } 1 \mathrm{~h} \text { of } \\
\text { incubation at } 37^{\circ} \mathrm{C} \text { in PBS medium; } 60.6 \% \text { after } 1 \mathrm{~h} \text { of } \\
\text { incubation at } 37^{\circ} \mathrm{C} \text { in real-contaminated sample using } 50 \mathrm{mg} / \mathrm{L} \\
\text { of extract }\end{array}$ & & \\
\hline $\begin{array}{l}\text { Thyme (Thymus } \\
\text { daenensis Celak) }\end{array}$ & Hydro-distillates & $\begin{array}{l}\text { Up to } 97 \% \text { of } A F B_{1} \text { degradation }(2,000 \mu \mathrm{g} / \mathrm{L}) \text { using } 2,000 \mathrm{mg} / \mathrm{L} \\
\text { aqueous extract }\end{array}$ & n.p. & $\begin{array}{l}\text { Gorran et al. } \\
(2013)\end{array}$ \\
\hline $\begin{array}{l}\text { Savory (Satureja } \\
\text { khuzestanica) }\end{array}$ & & $\begin{array}{l}\text { Up to } 5 \% \text { of } \mathrm{AFB}_{1} \text { degradation }(2,000 \mu \mathrm{g} / \mathrm{L}) \text { using } 2,000 \mathrm{mg} / \mathrm{L} \\
\text { aqueous extract }\end{array}$ & & \\
\hline $\begin{array}{l}\text { Savory (Satureja } \\
\text { macrosiphonia } \\
\text { Bornm) }\end{array}$ & & $\begin{array}{l}\text { Up to } 13 \% \text { of } A F B_{1} \text { degradation }(2,000 \mu \mathrm{g} / \mathrm{L}) \text { using } 2,000 \mathrm{mg} / \mathrm{L} \\
\text { aqueous extract }\end{array}$ & & \\
\hline $\begin{array}{l}\text { Ajowan } \\
\text { (Trachyspermum } \\
\text { ammi L.) Sprague } \\
\text { ex Turrill }\end{array}$ & $\begin{array}{l}\text { Seeds aqueous } \\
\text { extract }\end{array}$ & $\begin{array}{l}\text { Up to } 61 \% \text { of } \mathrm{AFB}_{1} \text { degradation after incubation at } 38^{\circ} \mathrm{C} \text { for } \\
48 \mathrm{~h}\end{array}$ & $\begin{array}{l}\text { No chromosomal } \\
\text { aberrations induced } \\
\text { in corn }\end{array}$ & $\begin{array}{l}\text { Velazhahan } \\
\text { et al. (2010) }\end{array}$ \\
\hline \multirow[t]{2}{*}{$\begin{array}{l}\text { Basil (Ocimum } \\
\text { tenuiflorum L.) }\end{array}$} & $\begin{array}{l}\text { Leaves aqueous } \\
\text { extract }\end{array}$ & $\begin{array}{l}\text { Up to } 74.7 \% \text { of } \mathrm{AFB}_{1} \text { degradation after incubation at } 85^{\circ} \mathrm{C} \text { for } \\
4 \mathrm{~h} \text {; }\end{array}$ & $\begin{array}{l}73.7 \% \text { of } \\
\text { cytotoxicity } \\
\text { reduction on Hela } \\
\text { cells }\end{array}$ & $\begin{array}{l}\text { Panda and } \\
\text { Mehta (2013) }\end{array}$ \\
\hline & & $\begin{array}{l}\text { Up to } 70.2 \% \text { of } A F B_{1} \text { degradation }(1 \mu \mathrm{g} / \mathrm{g} \text {, spiked) in rice after } \\
4 \mathrm{~h} \text { of incubation at } 85^{\circ} \mathrm{C}\end{array}$ & & \\
\hline
\end{tabular}

n.p., not provided. 
with bacteriostatic or fungistatic effects can be used, or they can be applied in combination with other antimicrobial compounds in a "multiple-hurdle approach" (Prakash et al., 2015; Sudharsan et al., 2019). Few authors evaluated the application in food to reduce $\mathrm{AFB}_{1}$ contamination, mainly nuts like macadamia (Kalli et al., 2018) and pistachio (Khorasani et al., 2017), obtaining comparable results with respect to the in vitro analyses.

\section{Feed Applications}

Bioactive compounds are used in feed to enhance (i) the organoleptic characteristics of feed (as feed flavorings), (ii) feed stability (as antioxidants), and (iii) feed digestibility and gut flora stability (as zootechnical additives) [Regulation (EC) No 1831/2003, 2003].

The European Commission approved the use of linalool, thymol, eugenol, carvone, cinnamaldehyde, vanillin, carvacrol, citral, and limonene as flavorings in food products with no restriction. A stepwise approach was adopted to evaluate the safety of those compounds, including the evaluation of the structure-activity relationships, intake from current uses, toxicological threshold of concern, and available data on metabolism and toxicity [Commission Implementing Regulation (EU) No 872/2012, 2012].

Simple and substituted phenols like thymol and carvacrol, have been proposed so far as flavoring additives in feed for all animal species; thus, the demonstration of efficacy was not considered necessary for their approval by the European Food Safety Authority [EFSA], 2012. Thanks to their antioxidant capacity, these compounds enhance the stability, the quality, the palatability of animal feed, and prolong the shelf life.

The so-called "phytogenic" feed additives (PFAs) are simple or complex mixtures of compounds belonging to a wide variety of herbs, spices, EO, or non-volatile extracts, which can be used in feed for various purposes. PFAs can be applied as solid powders, granulated, or also in liquid form to premixtures or complete feeds (Steiner and Syed, 2015).

Bioactive compounds are widely used as zootechnical additives to increase animals weight gain and performance. A general positive effect was shown for feed intake, weight gain, and feed conversion rate in piglets, sows, and poultry, while inconsistent data were registered for apparent digestibility in piglets (Franz et al., 2010; Christaki et al., 2012; Zeng et al., 2015) possibly due to improved secretion of digestive enzymes and bile secretion (Hafeez et al., 2015). A positive effect on gut microbiota in monogastric animals was also reported by several authors (Tiihonen et al., 2010; Bento et al., 2013). On the contrary, there is still no evidence of the in vivo efficacy on ruminants, while discordant data are available from in vitro studies with ruminal models. EOs may improve nitrogen uptake and energy production but at the same time be toxic for the ruminal microbiota, which produces volatile fatty acid and inhibits ruminal methanogenesis (Giannenas et al., 2013).

Two feed additives made of a mixture of encapsulated EOs (carvacrol, methyl salicylate and L-menthol, thymol, D-carvone) from oregano (O. vulgare L.) and from caraway seed (Carum carvi L.) were positively evaluated by EFSA as growth enhancers for weaned piglets, chickens for fattening, chickens reared for laying, and minor avian species to the point of lay (European Food Safety Authority [EFSA], 2019a,b).

Despite the different uses in animal nutrition, the use as AFreducing agents in feed is still unexplored. To be used as a feed additive to reduce AF contamination, EOs shall undergo a scientific assessment by EFSA to assure that several requirements are met: (i) the chemical compound is fully characterized and safe to be used; (ii) it leads to an irreversible and effective detoxification; (iii) the products of the detoxification process are not harmful or are less harmful than the contaminant itself to animals, people, or the environment; and (iv) the chemical and organoleptic characteristics of the feed are not altered (Commission Regulation (EU) 2015/786, 2015). A clear gap of knowledge for the identification of the degradation products and the evaluation of their toxicity currently limits this application.

In vivo studies often show low reliability because the EO composition is usually not fully characterized and active compounds quantified; the effects are not clearly defined because there may be differences in gastrointestinal tract anatomy and functionality also within the same species. When the studies are commercially oriented, some information may be voluntarily scarce (Stevanović et al., 2018). Eventually, limited information is available regarding the interaction between EOs and feed ingredients or other feed additives, such as fibers, probiotics, vitamins, and organic acids (Zeng et al., 2015).

\section{CONCLUSION AND FUTURE PERSPECTIVES}

Bioactive compounds from plant species are recognized for their pharmacological and nutraceutical value and are endowed with antifungal and antiaflatoxin activities.

The application of natural compounds deriving from plants to control aflatoxigenic fungi and AF production has been explored mostly in vitro in the last 10 years. The mechanisms of action are diverse and mainly target the cell wall, the plasmatic membrane, proteins, and the mitochondrial functionality of fungal cells. Some compounds also act as downregulators of AF biosynthetic pathway, while others have a direct degrading activity toward AF molecules. Limited studies evaluate the applicability of such compounds in food and feed to reduce Aspergillus spp. and AFs contamination. Nonetheless, many compounds possess the GRAS status and can be used as food and feed additives in Europe. Bioactive compounds are used as flavoring, antioxidant, and zootechnical additives to improve weight gain and digestibility of feeds in nonruminant species. Exploring new technologies to extract and use antifungal compounds from food wastes, such as olive oil wastewater or winery by-products, or to deliver such compounds can increase sustainability and lower the cost of these compounds. 
Enriching and expanding the genetic repertoire of plant secondary metabolites could help in increasing the plant defense systems. The identification of biosynthetic pathways, plant-host interactions, and varieties with higher content of bioactive compounds are crucial to allow the production of molecules of high commercial value and to improve the safety and quality of plant products. Another possible strategy to counteract AF contamination may be to increase the production of bioactive compound in susceptible commodities.

The major challenges that have to be overcome are the characterization of the active(s) compounds, the standardization of doses and biological activity, the evaluation of interactions in the field or with the food/feed matrix, the identification and the toxicological characterization of the degradation products in the case of the application to AF-contaminated commodities. Nonetheless, the potentialities of these compounds are diverse and may represent a powerful to counteract Aspergillus spp. contamination and AF production both in preand postharvest.

\section{REFERENCES}

Alotaibi, M. A., Tayel, A. A., Zidan, N. S., and El Rabey, H. A. (2019). Bioactive coatings from nano-biopolymers/plant extract composites for complete protection from mycotoxigenic fungi in dates. J. Sci. Food Agric. 99, 4338-4343. doi: 10.1002/jsfa.9667

Ansari, M. A., Anurag, A., Fatima, Z., and Hameed, S. (2013). "Natural phenolic compounds: a potential antifungal agent," in Microbial Pathogens and Strategies for Combating Them: Science, Technology and Education, ed. A. Méndez-Vilas, (Badajoz: Formatex Research Center), 189-195.

Azmir, J., Zaidul, I. S. M., Rahman, M. M., Sharif, K. M., Mohamed, A., Sahena, F., et al. (2013). Techniques for extraction of bioactive compounds from plant materials: a review. J. Food Eng. 117, 426-436. doi: 10.1016/j.jfoodeng.2013. 01.014

Badr, A. N., Shehata, M. G., and Abdel-Razek, A. G. (2017). Antioxidant activities and potential impacts to reduce aflatoxins utilizing jojoba and jatropha oils and extracts. Int. J. Pharmacol. 13, 1103-1114. doi: 10.3923/ijp.2017.1103.1114

Bakkali, F., Averbeck, S., Averbeck, D., and Idaomar, M. (2008). Biological effects of essential oils-a review. Food Chem. Toxicol. 46, 446-475. doi: 10.1016/j.fct. 2007.09.106

Bakry, A. M., Abbas, S., Ali, B., Majeed, H., Abouelwafa, M. Y., Ahmed, M., et al. (2016). Microencapsulation of oils: a comprehensive review of benefits, techniques, and applications. Compr. Rev. Food Sci. Food Saf. 15, 143-182. doi: 10.1111/1541-4337.12179

Bang, K. H., Lee, D. W., Park, H. M., and Rhee, Y. H. (2000). Inhibition of fungal cell wall synthesizing enzymes by trans-cinnamaldehyde. Biosci. Biotechnol. Biochem. 64, 1061-1063. doi: 10.1271/bbb.64.1061

Bassolé, I. H. N., and Juliani, H. R. (2012). Essential oils in combination and their antimicrobial properties. Molecules 17, 3989-4006. doi: 10.3390/ molecules17043989

Ben Arfa, A., Combes, S., Preziosi-Belloy, L., Gontard, N., and Chalier, P. (2006). Antimicrobial activity of carvacrol related to its chemical structure. Lett. Appl. Microbiol 43, 149-154. doi: 10.1111/j.1472-765X.2006.01938.x

Bento, M. H. L., Ouwehand, A. C., Tiihonen, K., Lahtinen, S., Nurminen, P., Saarinen, M., et al. (2013). Essential oils and their use in animal feeds for monogastric animals - effects on feed quality, gut microbiota, growth performance and food safety: a review. Vet. Med. 58, 449-458. doi: 10.17221/ 7029-VETMED

Bones, A. M., Hara, M., Rossiter, J. T., and Kissen, R. (2015). Physiology and cellular mechanisms of isothiocyanates and other glucosinolate degradation products in plants. Front. Plant Sci. 6:1105. doi: 10.3389/fpls.2015. 01105

\section{AUTHOR CONTRIBUTIONS}

ML and CP wrote the manuscript. AL conceived the review. GM coordinated the contributions. All authors contributed to manuscript revision, read and approved the submitted version.

\section{FUNDING}

This work was financially supported by H2020-E.U.3.2-678781 MycoKey integrated and innovative key actions for mycotoxin management in the food and feed chain.

\section{ACKNOWLEDGMENTS}

The authors acknowledge Dr. Maria Quarto and Mr. Roberto Schena of the Institute of Sciences of Food ProductionCNR for the skilled technical support provided during the realization of this work.

Branà, M. T., Sergio, L., Haidukowski, M., Logrieco, A. F., and Altomare, C. (2020). Degradation of Aflatoxin B1 by a sustainable enzymatic extract from spent mushroom substrate of Pleurotus eryngii. Toxins 12:E49. doi: 10.3390/ toxins12010049

Castelli, M. V., Lodeyro, A. F., Malheiros, A., Zacchino, S. A., and Roveri, O. A. (2005). Inhibition of the mitochondrial ATP synthesis by polygodial, a naturally occurring dialdehyde unsaturated sesquiterpene. Biochem. Pharmacol. 70, 8289. doi: 10.1016/j.bcp.2005.04.016

Chaves Lobón, N., Ferrer de la Cruz, I., and Alías Gallego, J. C. (2019). Autotoxicity of diterpenes present in leaves of Cistus ladanifer L. Plants 8:27. doi: 10.3390/ plants8020027

Christaki, E., Bonos, E., Giannenas, I., and Florou-Paneri, P. (2012). Aromatic plants as a source of bioactive compounds. Agriculture 2, 228-243. doi: 10.3390/ agriculture 2030228

Commission Implementing Regulation (EU) No 872/2012, (2012). Commission Implementing Regulation (EU) No 872/2012 The list of Flavouring Substances Provided for by Regulation (EC) No 2232/96 of the European Parliament and of the Council, introducing it in Annex I to Regulation (EC) No 1334/2008 of the European Parliament and of the Council and repealing Commission Regulation (EC) No 1565/2000 and Commission Decision 1999/217/EC. Available at: http: //data.europa.eu/eli/reg_impl/2012/872/oj (accessed October 1, 2012).

Commission Regulation (EU) 2015/786, (2015). Commission Regulation (EU) 2015/786 Defining Acceptability Criteria for Detoxification Processes Applied to Products Intended for Animal Feed as Provided for in Directive 2002/32/EC of the European Parliament and of the Council. Available at: http://data.europa.eu/ eli/reg/2015/786/oj (accessed May 19, 2015).

da Rosa, C. G., Maciel, M. V. D. O. B., de Carvalho, S. M., de Melo, A. P. Z., Jummes, B., da Silva, T., et al. (2015). Characterization and evaluation of physicochemical and antimicrobial properties of zein nanoparticles loaded with phenolics monoterpenes. Colloids Surf. Physicochem. Eng. Aspects 481, 337-344. doi: 10.1016/j.colsurfa.2015.05.019

Dambolena, J. S., Zygadlo, J. A., and Rubinstein, H. R. (2011). Antifumonisin activity of natural phenolic compounds: a structure-propertyactivity relationship study. ýInt. J. Food Microbiol. 145, 140-146. doi: 10.1016/j.ijfoodmicro.2010.12.001

Das, S., Singh, V. K., Dwivedy, A. K., Chaudhari, A. K., Upadhyay, N., Singh, P., et al. (2019). Encapsulation in chitosan-based nanomatrix as an efficient green technology to boost the antimicrobial, antioxidant and in situ efficacy of Coriandrum sativum essential oil. Int. J. Biol. Macromol. 133, 294-305. doi: 10.1016/j.ijbiomac.2019.04.070

Depuydt, S., Van Praet, S., Nelissen, H., Vanholme, B., and Vereecke, D. (2016). "How plant hormones and their interactions affect cell growth," in Molecular 
Cell Biology of the Growth and Differentiation of Plant Cells, ed. R. J. Rose, (Boca Raton, FL: CRC Press), 174-195. doi: 10.1201/b20316-14

Dwivedy, A. K., Singh, V. K., Prakash, B., and Dubey, N. K. (2018). Nanoencapsulated Illicium verum Hook. f. essential oil as an effective novel plant-based preservative against aflatoxin $\mathrm{B} 1$ production and free radical generation. Food Chem. Toxicol. 111, 102-113. doi: 10.1016/j.fct.2017.11.007

European Commission, (2006). Commission Regulation (EC) No 1881/2006 of 19 December 2006 Setting Maxirtain Contaminants in Foodstuffs. Available at: http://data.europa.eu/eli/reg/2006/1881/oj (accessed September 12, 2019).

European Food Safety Authority [EFSA], (2012). Scientific Opinion on the safety and efficacy of phenol derivatives containing ring-alkyl, ring-alkoxy and sidechains with an oxygenated functional group (chemical group 25) when used as flavourings for all species. Panel Addit. Prod. Substan. Anim. Feed 10, 2573. doi: $10.2903 /$ j.efsa.2012.2573

European Food Safety Authority [EFSA], (2019a). FEEDAP Panel (EFSA Panel on Additives and Products or Substances used in Animal Feed) Bampidis, V., Azimonti, G., Bastos, M.L., Christensen, H., Dusemund, B., Kouba, M., Kos Durjava. M., Lopez-Alonso, M., Lopez Puente, S., Marcon, F., Mayo, B., Pechova, A., Petkova, M., Ramos, F., Sanz, Y., Villa. R, E, Woutersen. R, Chesson, A., Gropp, J., Martelli, G., Renshaw, D., Lopez-Galvez, G.,. Mantovani, A. 2019. Scientific Opinion on the safety and efficacy of Biomin ${ }^{\circledR}$ DC-C as a zootechnical feed additive forweaned piglets. EFSA Journal 17, 5688. doi: 10.2903/j.efsa.2019.5688

European Food Safety Authority [EFSA], (2019b). FEEDAP Panel (EFSA Panel on Additives and Products or Substances used in Animal Feed), Bampidis, V., Azimonti, G., Bastos, M.L., Christensen, H., Dusemund, B., Kouba, M., Kos Durjava. M., Lopez-Alonso, M., Lopez Puente, S., Marcon, F., Mayo, B., Pechova, A., Petkova, M., Ramos, F., Sanz, Y., Villa. R,E, Woutersen. R, Chesson, A., Gropp, J., Martelli, G., Renshaw, D., Lopez-Galvez, G. Mantovani, A. 2019. Scientific Opinion on the safety and efficacy of Biomin ${ }^{\circledR}$ DC-P as a zootechnical feed additive for chickens for fattening,chickens reared for laying and minor avian species to the point of lay. EFSA J. 17:5724. doi: 10.2903/j.efsa. 2019.5724

Feliziani, E., Landi, L., and Romanazzi, G. (2015). Preharvest treatments with chitosan and other alternatives to conventional fungicides to control postharvest decay of strawberry. Carbohyd. Polym. 132, 111-117. doi: 10.1016/ j.carbpol.2015.05.078

Ferreira, F. D., Kemmelmeier, C., Arrotéia, C. C., da Costa, C. L., Mallmann, C. A., Janeiro, V., et al. (2013). Inhibitory effect of the essential oil of Curcuma longa L. and curcumin on aflatoxin production by Aspergillus flavus Link. Food Chem. 136, 789-793. doi: 10.1016/j.foodchem.2012.08.003

Figueiredo, A. C., Barroso, J. G., Pedro, L. G., and Scheffer, J. J. C. (2008). Factors affecting secondary metabolite production in plants: volatile components and essential oils. Flavour Fragr. J. 23, 213-226. doi: 10.1002/ffj.1875

Firouzi, R., Shekarforoush, S. S., Nazer, A. H. K., Borumand, Z., and Jooyandeh, A. R. (2007). Effects of essential oils of oregano and nutmeg on growth and survival of Yersinia enterocolitica and Listeria monocytogenes in barbecued chicken. J. Food Prot. 70, 2626-2630. doi: 10.4315/0362-028X-70.11.2626

Franz, C., Baser, K. H. C., and Windisch, W. (2010). Essential oils and aromatic plants in animal feeding-a European perspective. A review. Flavour Fragr. J. 25, 327-340. doi: 10.1002/ffj.1967

Gao, M., Feng, L., and Jiang, T. (2014). Browning inhibition and quality preservation of button mushroom (Agaricus bisporus) by essential oils fumigation treatment. Food Chem. 149, 107-113. doi: 10.1016/j.foodchem.2013. 10.073

Georgianna, D. R., and Payne, G. A. (2009). Genetic regulation of aflatoxin biosynthesis: from gene to genome. Fungal Genet. Biol. 46, 113-125. doi: 10. 1016/j.fgb.2008.10.011

Ghasemzadeh, A., and Ghasemzadeh, N. (2011). Flavonoids and phenolic acids: role and biochemical activity in plants and human. J. Med. Plant Res. 5, 6697-6703. doi: 10.5897/JMPR11.1404

Giacometti, J., Kovaèević, D. B., Putnik, P., Gabrić, D., Bilušić, T., Krešić, G., et al. (2018). Extraction of bioactive compounds and essential oils from Mediterranean herbs by conventional and green innovative techniques: a review. Food Res. Int. 113, 245-262. doi: 10.1016/j.foodres.2018.06.036

Giannenas, I., Bonos, E., Christaki, E., and Florou-Paneri, P. (2013). Essential oils and their applications in animal nutrition. Med. Aromat. Plants 2:140. doi: 10.4172/2167-0412.1000140
Giteru, S. G., Coorey, R., Bertolatti, D., Watkin, E., Johnson, S., and Fang, Z. (2015). Physicochemical and antimicrobial properties of citral and quercetin incorporated kafirin-based bioactive films. Food Chem. 168, 341-347. doi: 10. 1016/j.foodchem.2014.07.077

Gómez, J. V., Tarazona, A., Mateo-Castro, R., Gimeno-Adelantado, J. V., Jiménez, M., and Mateo, E. M. (2018). Selected plant essential oils and their main active components, a promising approach to inhibit aflatoxigenic fungi and aflatoxin production in food. Food Addit. Contam. A 35, 1581-1595. doi: 10. 1080/19440049.2017.1419287

Gorran, A., Farzaneh, M., Shivazad, M., Rezaeian, M., and Ghassempour, A. (2013). Aflatoxin B1-reduction of Aspergillus flavus by three medicinal plants (Lamiaceae). Food Control 31, 218-223. doi: 10.1016/j.foodcont.2012.09.024

Gow, N. A. R., Latge, J. P., and Munro, C. A. (2017). The fungal cell wall: structure, biosynthesis, and function. Microbiol. Spectr. 5:FUNK-0035-2016. doi: 10.1128/ microbiolspec.FUNK-0035-2016.

Hafeez, A., Männer, K., Schieder, C., and Zentek, J. (2015). Effect of supplementation of phytogenic feed additives (powdered vs. encapsulated) on performance and nutrient digestibility in broiler chickens. Poult. Sci. 95, 622-629. doi: 10.3382/ps/pev368

Hu, Y., Kong, W., Yang, X., Xie, L., Wen, J., and Yang, M. (2014). GC-MS combined with chemometric techniques for the quality control and original discrimination of Curcumae longae rhizome: analysis of essential oils. J. Sep. Sci. 37, 404-411. doi: 10.1002/jssc.201301102

Hu, Y., Zhang, J., Kong, W., Zhao, G., and Yang, M. (2017). Mechanisms of antifungal and anti-aflatoxigenic properties of essential oil derived from turmeric (Curcuma longa L.) on Aspergillus flavus. Food Chem. 220, 1-8. doi: 10.1016/j.foodchem.2016.09.179

Hyldgaard, M., Mygind, T., and Meyer, R. L. (2012). Essential oils in food preservation: mode of action, synergies, and interactions with food matrix components. Front. Microbiol. 3:12. doi: 10.3389/fmicb.2012.00012

IARC. (2012). "Aflatoxins. Monographs on the Evaluation of Carcinogenic Risks to Humans. Chemical agents and related occupations: a review of human carcinogens," in Proceedings of the International Agency for the Research on Cancer, Vol. 100F, Lyon, 225-244.

Iram, W., Anjum, T., Iqbal, M., Ghaffar, A., and Abbas, M. (2015). Mass spectrometric identification and toxicity assessment of degraded products of aflatoxin B1 and B2 by Corymbia citriodora aqueous extracts. Sci. Rep. 5:14672. doi: $10.1038 /$ srep 14672

Iram, W., Anjum, T., Iqbal, M., Ghaffar, A., and Abbas, M. (2016a). Structural elucidation and toxicity assessment of degraded products of aflatoxin B1 and B2 by aqueous extracts of Trachyspermum ammi. Front. Microbiol. 7:346. doi: 10.3389/fmicb.2016.00346

Iram, W., Anjum, T., Iqbal, M., Ghaffar, A., Abbas, M., and Khan, A. M. (2016b). Structural analysis and biological toxicity of aflatoxins B1 and B2 degradation products following detoxification by Ocimum basilicum and Cassia fistula aqueous extracts. Front. Microbial. 7:1105. doi: 10.3389/fmicb.2016.01105

Jahanshiri, Z., Shams-Ghahfarokhi, M., Allameh, A., and Razzaghi-Abyaneh, M. (2015). Inhibitory effect of eugenol on aflatoxin B1 production in Aspergillus parasiticus by downregulating the expression of major genes in the toxin biosynthetic pathway. World J. Microbiol. Biotechnol. 31, 1071-1078. doi: 10. 1007/s11274-015-1857-7

Janatova, A., Bernardos, A., Smid, J., Frankova, A., Lhotka, M., Kourimská, L., et al. (2015). Long-term antifungal activity of volatile essential oil components released from mesoporous silica materials. Ind. Crops Prod. 67, 216-220. doi: 10.1016/j.indcrop.2015.01.019

Jefremova, M., Ostrý, V., Malíø, F., and Ruprich, J. (2016). Rapid diagnostic testing of toxigenic microfungi isolated from foodstuffs. Acta Vet. Brno 85, 151-156. doi: $10.2754 / \mathrm{avb} 201685020151$

Kalli, V., Kollia, E., Roidaki, A., Proestos, C., and Markaki, P. (2018). Cistus incanus L. extract inhibits aflatoxin B1 production by Aspergillus parasiticus in macadamia nuts. Ind. Crops Prod. 111, 63-68. doi: 10.1016/j.indcrop.2017.10. 003

Kaur, R., Rampal, G., and Vig, A. P. (2011). Evaluation of antifungal and antioxidative potential of hydrolytic products of glucosinolates from some members of Brassicaceae family. J. Plant Breed. Crop Sci. 3, 218-228.

Khorasani, S., Azizi, M. H., Barzegar, M., Hamidi-Esfahani, Z., and Kalbasi-Ashtari, A. (2017). Inhibitory effects of cinnamon, clove and celak extracts on growth of 
Aspergillus flavus and its aflatoxins after spraying on pistachio nuts before cold storage. J. Food Saf. 37:e12383. doi: 10.1111/jfs.12383

Kim, J. H., Campbell, B. C., Yu, J., Mahoney, N., Chan, K. L., Molyneux, R. J., et al. (2005). Examination of fungal stress response genes using Saccharomyces cerevisiae as a model system: targeting genes affecting aflatoxin biosynthesis by Aspergillus flavus Link. Appl. Microbiol. Biotechnol. 67, 807-815. doi: 10.1007/ s00253-004-1821-1

Kiran, S., Kujur, A., and Prakash, B. (2016). Assessment of preservative potential of Cinnamomum zeylanicum Blume essential oil against food borne molds, aflatoxin B1 synthesis, its functional properties and mode of action. Innov. Food Sci. Emerg. Technol. 37, 184-191. doi: 10.1016/j.ifset.2016.08.018

Kohiyama, C. Y., Ribeiro, M. M. Y., Mossini, S. A. G., Bando, E., da Silva Bomfim, N., Nerilo, S. B., et al. (2015). Antifungal properties and inhibitory effects upon aflatoxin production of Thymus vulgaris L. by Aspergillus flavus Link. Food Chem. 173, 1006-1010. doi: 10.1016/j.foodchem.2014.10.135

Kumar, A., Kujur, A., Yadav, A., Pratap, S., and Prakash, B. (2019). Optimization and mechanistic investigations on antifungal and aflatoxin B1 inhibitory potential of nanoencapsulated plant-based bioactive compounds. Ind. Crops Prod. 131, 213-223. doi: 10.1016/j.indcrop.2019.01.043

Kumar, P., Mahato, D. K., Kamle, M., Mohanta, T. K., and Kang, S. G. (2017). Aflatoxins: a global concern for food safety, human health and their management. Front. Microbial. 7:2170. doi: 10.3389/fmicb.2016.02170

Leslie, J. F., and Logrieco, A. (2014). Mycotoxin Reduction in Grain Chains. Hoboken, NJ: Wiley Blackwell.

Liang, D., Xing, F., Selvaraj, J. N., Liu, X., Wang, L., Hua, H., et al. (2015). Inhibitory effect of cinnamaldehyde, citral, and eugenol on aflatoxin biosynthetic gene expression and aflatoxin B1 biosynthesis in Aspergillus flavus. J. Food Sci. Technol. 80, M2917-M2924. doi: 10.1111/1750-3841.13144

Liuzzi, V. C., Fanelli, F., Tristezza, M., Haidukowski, M., Picardi, E., Manzari, C., et al. (2017). Transcriptional analysis of Acinetobacter sp. negl capable of degrading ochratoxin A. Front. Microbiol. 7:2162. doi: 10.3389/fmicb.2016. 02162

Loi, M., Fanelli, F., Cimmarusti, M. T., Mirabelli, V., Haidukowski, M., Caliandro, R., et al. (2018). In vitro single and combined mycotoxins degradation by Ery4 laccase from Pleurotus eryngii and redox mediators. Food Control 90, 401-406. doi: 10.1016/j.foodcont.2018.02.032

Loi, M., Fanelli, F., Liuzzi, V. C., Logrieco, A. F., and Mulè, G. (2017). Mycotoxin biotransformation by native and commercial enzymes: present and future perspectives. Toxins 9:111. doi: 10.3390/toxins9040111

Loi, M., Fanelli, F., Zucca, P., Liuzzi, V. C., Quintieri, L., Cimmarusti, M. T., et al. (2016). Aflatoxin $B_{1}$ and $M_{1}$ Degradation by Lac2 from Pleurotus pulmonarius and Redox Mediators. Toxins 8:245. doi: 10.3390/toxins8090245

Lopes, L. F., Bordin, K., de Lara, G. H., Saladino, F., Quiles, J. M., Meca, G., et al. (2018). Fumigation of Brazil nuts with allyl isothiocyanate to inhibit the growth of Aspergillus parasiticus and aflatoxin production. J. Sci. Food Agric. 98, 792-798. doi: 10.1002/jsfa.8527

Lv, C., Wang, P., Ma, L., Zheng, M., Liu, Y., and Xing, F. (2018). Largescale comparative analysis of eugenol-induced/repressed genes expression in Aspergillus flavus using RNA-seq. Front. Microbiol. 9:1116. doi: 10.3389/fmicb. 2018.01116

Lyagin, I., and Efremenko, E. (2019). Enzymes for detoxification of various mycotoxins: origins and mechanisms of catalytic action. Molecules 24:2362. doi: $10.3390 /$ molecules 24132362

Mahato, D. K., Lee, K. E., Kamle, M., Devi, S., Dewangan, K., Kumar, P., et al. (2019). Aflatoxins in food and feed: an overview on prevalence, detection and control strategies. Front. Microbiol. 10:2266. doi: 10.3389/fmicb.2019.02266

Mahuku, G., Nzioki, H. S., Mutegi, C., Kanampiu, F., Narrod, C., and Makumbi, D. (2019). Pre-harvest management is a critical practice for minimizing aflatoxin contamination of maize. Food Control 96, 219-226. doi: 10.1016/j.foodcont. 2018.08.032

Manyes, L., Luciano, F. B., Mañes, J., and Meca, G. (2015). In vitro antifungal activity of allyl isothiocyanate (AITC) against Aspergillus parasiticus and Penicillium expansum and evaluation of the AITC estimated daily intake. Food Chem. Toxicol. 83, 293-299. doi: 10.1016/j.fct.2015.06.011

Marei, G. I. K., Rasoul, M. A. A., and Abdelgaleil, S. A. (2012). Comparative antifungal activities and biochemical effects of monoterpenes on plant pathogenic fungi. Pest Biochem. Physiol. 103, 56-61. doi: 10.1016/j.pestbp.2012. 03.004
Mateo, E. M., Gómez, J. V., Domínguez, I., Gimeno-Adelantado, J. V., MateoCastro, R., Gavara, R., et al. (2017). Impact of bioactive packaging systems based on EVOH films and essential oils in the control of aflatoxigenic fungi and aflatoxin production in maize. Int. J. Food Microbiol. 254, 36-46. doi: 10.1016/j.ijfoodmicro.2017.05.007

Miguel, M. G. (2010). Antioxidant and anti-inflammatory activities of essential oils: a short review. Molecules 15, 9252-9287. doi: 10.3390/molecules 15129252

Mithöfer, A., and Maffei, M. E. (2017). General mechanisms of plant defense and plant toxins. Plant Toxins 3-24. doi: 10.1007/978-94-007-6728-7_21-1

Moon, Y. S., Lee, H. S., and Lee, S. E. (2018). Inhibitory effects of three monoterpenes from ginger essential oil on growth and aflatoxin production of Aspergillus flavus and their gene regulation in aflatoxin biosynthesis. Appl. Biol. Chem. 61, 243-250. doi: 10.1007/s13765-018-0352-x

Moretti, A., Pascale, M., and Logrieco, A. F. (2019). Mycotoxin risks under a climate change scenario in Europe. Trends Food Sci. Technol. 84, 38-40. doi: 10.1016/j.tifs.2018.03.008

Moretti, A., and Susca, A. (2017). "Mycotoxigenic fungi: methods and protocols," in Methods in Enzimology, Vol. vol. 1542, eds A. Moretti, and A. Susca, (New York, NY: Humana Press), doi: 10.1007/978-1-4939-6707-0

Nazareth, T. M., Bordin, K., Manyes, L., Meca, G., Mañes, J., and Luciano, F. B. (2016). Gaseous allyl isothiocyanate to inhibit the production of aflatoxins, beauvericin and enniatins by Aspergillus parasiticus and Fusarium poae in wheat flour. Food Control 62, 317-321. doi: 10.1016/j.foodcont.2015.11.003

Negera, M., and Washe, A. P. (2019). Use of natural dietary spices for reclamation of food quality impairment by aflatoxin. J. Food Qual. 2019:4371206. doi: 10. $1155 / 2019 / 4371206$

Neme, K., and Mohammed, A. (2017). Mycotoxin occurrence in grains and the role of postharvest management as a mitigation strategies. A review. Food Control 78, 412-425. doi: 10.1016/j.foodcont.2017.03.012

Omidpanah, S., Sadeghi, H., Sarcheshmeh, M. M., and Manayi, A. (2015). Evaluation of antifungal activity of aqueous extracts of some medicinal plants against Aspergillus flavus, pistachio aflatoxin producing fungus in vitro. Drug Des. Dev. Ther. 6, 66-69. doi: 10.4103/2394-6555.162446

Onaran, A., and Yanar, Y. (2016). In vivo and in vitro antifungal activities of five plant extracts against various plant pathogens. Egypt. J. Biol. Pest Control 26, 405. doi: 10.1016/j.pestbp.2018.07.001

OuYang, Q., Tao, N., and Jing, G. (2016). Transcriptional profiling analysis of Penicillium digitatum, the causal agent of citrus green mold, unravels an inhibited ergosterol biosynthesis pathway in response to citral. BMC Genomics 17:599. doi: 10.1186/s12864-016-2943-4

Panda, P., and Mehta, A. (2013). Aflatoxin detoxification potential of Ocimum Tenuiflorum. J. Food Saf. 33, 265-272. doi: 10.1111/jfs.12048

Peretto, G., Du, W. X., Avena-Bustillos, R. J., Sarreal, S. B. L., Hua, S. S. T., Sambo, P., et al. (2014). Increasing strawberry shelf-life with carvacrol and methyl cinnamate antimicrobial vapors released from edible films. Postharvest Biol. Technol. 89, 11-18. doi: 10.1016/j.postharvbio.2013.11.003

Pichersky, E., and Raguso, R. A. (2018). Why do plants produce so many terpenoid compounds? New Phytol. 220, 692-702. doi: 10.1111/nph.14178

Pinto, E., Hrimpeng, K., Lopes, G., Vaz, S., Gonçalves, M. J., Cavaleiro, C., et al. (2013). Antifungal activity of Ferulago capillaris essential oil against Candida, Cryptococcus, Aspergillus and dermatophyte species. Eur. J Clin. Microbiol. Infect Dis. 32, 1311-1320. doi: 10.1007/s10096-013-1881-1

Pisoschi, A. M., Pop, A., Cimpeanu, C., and Predoi, G. (2016). Antioxidant capacity determination in plants and plant-derived products: a review. Oxid. Med. Cell. Longev. 2016:9130976. doi: 10.1155/2016/9130976

Ponzilacqua, B., Rottinghaus, G. E., Landers, B. R., and Oliveira, C. A. F. (2019). Effects of medicinal herb and Brazilian traditional plant extracts on in vitro mycotoxin decontamination. Food Control 100, 24-27. doi: 10.1016/j.foodcont. 2019.01.009

Prakash, B., Kedia, A., Mishra, P. K., and Dubey, N. K. (2015). Plant essential oils as food preservatives to control moulds, mycotoxin contamination and oxidative deterioration of agri-food commodities-Potentials and challenges. Food Control 47, 381-391. doi: 10.1016/j.foodcont.2014.07.023

Quiles, J. M., Manyes, L., Luciano, F., Manes, J., and Meca, G. (2015). Influence of the antimicrobial compound allyl isothiocyanate against the Aspergillus parasiticus growth and its aflatoxins production in pizza crust. Food Chem. Toxicol. 83, 222-228. doi: 10.1016/j.fct.2015. 06.017 
Quiles, J. M., Nazareth, T. D. M., Luz, C., Luciano, F. B., Mañes, J., and Meca, G. (2019). Development of an Antifungal and Antimycotoxigenic Device Containing Allyl Isothiocyanate for Silo Fumigation. Toxins 11:E137. doi: 10. 3390/toxins11030137

Rammanee, K., and Hongpattarakere, T. (2011). Effects of tropical citrus essential oils on growth, aflatoxin production, and ultrastructure alterations of Aspergillus flavus and Aspergillus parasiticus. Food Bioprocess Technol. 4, 1050-1059. doi: 10.1007/s11947-010-0507-1

Rao, A., Zhang, Y., Muend, S., and Rao, R. (2010). Mechanism of antifungal activity of terpenoid phenols resembles calcium stress and inhibition of the TOR pathway. Antimicrob. Agents Chemother. 54, 5062-5069. doi: 10.1128/ AAC.01050-10

Regulation (EC) No 1831/2003, (2003). European Parliament, and of the Council of 22 September 2003 on Additives for Use in Animal Nutrition (OJ L 268, 18.10.2003). Available at: https://eur-lex.europa.eu/legal-content/EN/LSU/ ?uri=CELEX:02003R1831-20151230, 29-43 (accessed September 12, 2019).

Reverberi, M., Fabbri, A. A., Zjalic, S., Ricelli, A., Punelli, F., and Fanelli, C. (2005). Antioxidant enzymes stimulation in Aspergillus parasiticus by Lentinula edodes inhibits aflatoxin production. Appl. Microbiol. Biotechnol. 69, 207-215. doi: 10.1007/s00253-005-1979- 1

Reverberi, M., Ricelli, A., Zjalic, S., Fabbri, A. A., and Fanelli, C. (2010). Natural functions of mycotoxins and control of their biosynthesis in fungi. Appl. Microbiol. Biotechnol. 87, 899-911. doi: 10.1007/s00253-010-2657-5

Reverberi, M., Zjalic, S., Ricelli, A., Fabbri, A. A., and Fanelli, C. (2006). Oxidant/antioxidant balance in Aspergillus parasiticus affects aflatoxin biosynthesis. Mycotoxin Res. 22, 39-47. doi: 10.1007/BF02954556

Saladino, F., Bordin, K., Manyes, L., Luciano, F. B., Manes, J., Fernández-Franzón, M., et al. (2016). Reduction of the aflatoxins B1, B2, G1 and G2 in Italian piadina by isothiocyanates. LWT Food Sci. Technol. 70, 302-308. doi: 10.1016/j.lwt.2016. 03.006

Sant, D. G., Tupe, S. G., Ramana, C. V., and Deshpande, M. V. (2016). Fungal cell membrane-promising drug target for antifungal therapy. J. Appl. Microbiol. 121, 1498-1510. doi: 10.1111/jam.13301

Sharma, M., Koul, A., Sharma, D., Kaul, S., Swamy, M. K., and Dhar, M. K. (2019). "Metabolic engineering strategies for enhancing the production of bio-active compounds from medicinal plants," in Natural Bio-active Compounds, eds M. Akhtar, and M. Swamy, (Singapore: Springer), doi: 10.1007/978-981-13-7438$8 \_12$

Sharma, N., and Tripathi, A. (2008). Effects of Citrus sinensis (L.) Osbeck epicarp essential oil on growth and morphogenesis of Aspergillus niger (L.) Van Tieghem. Microbiol. Res. 163, 337-344. doi: 10.1016/j.micres.2006. 06.009

Shen, Q., Zhou, W., Li, H., Hu, L., and Mo, H. (2016). ROS involves the fungicidal actions of thymol against spores of Aspergillus flavus via the induction of nitric oxide. PLoS One 11:e0155647. doi: 10.1371/journal.pone.0155647

Sivakumar, D., and Bautista-Baños, S. (2014). A review on the use of essential oils for postharvest decay control and maintenance of fruit quality during storage. Crop Prot. 64, 27-37. doi: 10.1016/j.cropro.2014.05.012

Steiner, T., and Syed, B. (2015). "Phytogenic feed additives in animal nutrition," in Medicinal and Aromatic Plants of the World, ed. Á Máthé, (Dordrecht: Springer), 403-423. doi: 10.1007/978-94-0179810-5_20

Stevanović, Z., Bošnjak-Neumüller, J., Pajić-Lijaković, I., Raj, J., and Vasiljević, M. (2018). Essential oils as feed additives-future perspectives. Molecules 23:1717. doi: 10.3390/molecules 23071717

Sudharsan, S., Shapiro, O., Ziv, C., Barda, O., Zakin, V., and Sionov, E. (2019). Synergistic Inhibition of Mycotoxigenic Fungi and Mycotoxin Production by Combination of Pomegranate Peel Extract and Azole Fungicide. Front. Microbiol. 10:1919. doi: 10.3389/fmicb.2019.01919

Sun, Q., Shang, B., Wang, L., Lu, Z., and Liu, Y. (2016). Cinnamaldehyde inhibits fungal growth and aflatoxin B 1 biosynthesis by modulating the oxidative stress response of Aspergillus flavus. Appl. Microbiol. Biot. 100, 1355-1364. doi: 10.1007/s00253-015-7159-z

Tabassum, N., and Vidyasagar, G. M. (2013). Antifungal investigations on plant essential oils. A review. Int. J. Pharm. Pharm. Sci. 5, 19-28.
Tian, J., Ban, X., Zeng, H., He, J., Chen, Y., and Wang, Y. (2012a). The mechanism of antifungal action of essential oil from dill (Anethum graveolens L.) on Aspergillus flavus. PLoS One 7:e30147. doi: 10.1371/journal.pone.0030147

Tian, J., Ban, X., Zeng, H., He, J., Huang, B., and Wang, Y. (2011). Chemical composition and antifungal activity of essential oil from Cicuta virosa L. var. latisecta Celak. ýInt. J. Food Microbiol. 145, 464-470. doi: 10.1016/j.ijfoodmicro. 2011.01 .023

Tian, J., Huang, B., Luo, X., Zeng, H., Ban, X., He, J., et al. (2012b). The control of Aspergillus flavus with Cinnamomum jensenianum Hand.-Mazz essential oil and its potential use as a food preservative. Food Chem. 130, 520-527. doi: 10.1016/j.foodchem.2011.07.061

Tiihonen, K., Kettunen, H., Bento, M. H. L., Saarinen, M., Lahtinen, S., Ouwehand, A. C., et al. (2010). The effect of feeding essential oils on broiler performance and gut microbiota. Br. Poult. Sci. 51, 381-392. doi: 10.1080/00071668.2010. 496446

Tracz, B. L., Bordin, K., de Melo Nazareth, T., Costa, L. B., de Macedo, R. E. F., Meca, G., et al. (2017). Assessment of allyl isothiocyanate as a fumigant to avoid mycotoxin production during corn storage. LWT Food Sci. Technol. 75, 692-696. doi: 10.1016/j.lwt.2016.10.030

Upadhyay, S., and Dixit, M. (2015). Role of polyphenols and other phytochemicals on molecular signaling. Oxid. Med. Cell. Longev. 2015:504253. doi: 10.1155/ $2015 / 504253$

Velazhahan, R., Vijayanandraj, S., Vijayasamundeeswari, A., Paranidharan, V., Samiyappan, R., Iwamoto, T., et al. (2010). Detoxification of aflatoxins by seed extracts of the medicinal plant, Trachyspermum ammi (L.) Sprague ex Turrill-structural analysis and biological toxicity of degradation product of aflatoxin G1. Food Control 21, 719-725. doi: 10.1016/j.foodcont.2009. 10.014

Vijayanandraj, S., Brinda, R., Kannan, K., Adhithya, R., Vinothini, S., Senthil, K., et al. (2014). Detoxification of aflatoxin B1 by an aqueous extract from leaves of Adhatoda vasica Nees. Microbiol. Res. 169, 294-300. doi: 10.1016/j.micres.2013. 07.008

Walters, D. (2011). Plant Defense: Warding off Attack by Pathogens, Herbivores and Parasitic Plants. Hoboken, NJ: Blackwell Publishing. doi: 10.1002/ 9781444328547

Wu, Y., Luo, Y., and Wang, Q. (2012). Antioxidant and antimicrobial properties of essential oils encapsulated in zein nanoparticles prepared by liquid-liquid dispersion method. LWT Food Sci. Technol. 48, 283-290. doi: 10.1016/j.lwt. 2012.03.027

Xie, X. M., Fang, J. R., and Xu, Y. (2004). Study of antifungal effect of cinnamaldehyde and citral on Aspergillus flavus. Food Sci. 25, 32-34.

Xie, Y., Huang, Q., Wang, Z., Cao, H., and Zhang, D. (2017). Structureactivity relationships of cinnamaldehyde and eugenol derivatives against plant pathogenic fungi. Ind. Crops Prod. 97, 388-394. doi: 10.1016/j.indcrop.2016.12. 043

Yu, J., Chang, P. K., Ehrlich, K. C., Cary, J. W., Bhatnagar, D., Cleveland, T. E., et al. (2004). Clustered pathway genes in aflatoxin biosynthesis. Appl. Environ. Microbiol. 70, 1253-1262. doi: 10.1128/AEM.70.3.1253-1262.2004

Zeng, Z., Zhang, S., Wang, H., and Piao, X. (2015). Essential oil and aromatic plants as feed additives in non-ruminant nutrition: a review. J. Anim. Sci. Biotechnol. 6:7. doi: 10.1186/s40104-015-0004-5

Zhang, H., and Tsao, R. (2016). Dietary polyphenols, oxidative stress and antioxidant and anti-inflammatory effects. Curr. Opin. Food Sci. 8, 33-42. doi: 10.1016/j.cofs.2016.02.002

Conflict of Interest: The authors declare that the research was conducted in the absence of any commercial or financial relationships that could be construed as a potential conflict of interest.

Copyright (C) 2020 Loi, Paciolla, Logrieco and Mulè. This is an open-access article distributed under the terms of the Creative Commons Attribution License (CC BY). The use, distribution or reproduction in other forums is permitted, provided the original author(s) and the copyright owner(s) are credited and that the original publication in this journal is cited, in accordance with accepted academic practice. No use, distribution or reproduction is permitted which does not comply with these terms. 